\title{
Geology and geochemistry of Bois River Suite, Mara Rosa (GO): evidence of magmatic arc paleoproterozoic
}

\author{
Said Abdallah ${ }^{1 *}$ \\ ${ }^{1}$ Geological Survey of Brazil (CPRM) - \\ Goiânia (GO), Brazil. \\ *Corresponding author: said.abdallah@ \\ cprm.gov.br
}

\begin{abstract}
The Bois River Headwaters Suite of, Rosa Mara-Nova Iguaçu (Goiás, Brazil) region, are granitoids to granodioritic and tonalitic with peraluminous characteristics, as distinguished granodiorite VI, granodiorite MU and tonalite SJ, which host gold occurrences. Under the aspect of regional geology, these bodies are intrusive in Santa Terezinha Sequence, and correlate regionally through petrographic and geochemical similarities with Aurmina Suite. These rocks fall into a system collisional to post-collisional, possibly related to the evolution of the magmatic arc paleoproterozoic. Lithogeochemistry showed values in similar reasons $\mathrm{MgO} / \mathrm{TiO}_{2}$, suggesting "trend" and evolutive aspect of lower fractionation of elements. In terms of tectonic setting, this suite is calc-alkaline magmatism to crustal contamination or collisional granites type $\mathrm{A} 2$, impoverished in $\mathrm{Rb}$ and $\mathrm{Y}$. The main changes observed were biotitization, hydrothermal propylitic, sericitic and silicification. Mineral chemical analyzes of biotite and muscovite confirmed distinct generations of these mineral phases, resulting from hydrothermal alteration. The primary biotite, without rebalancing, is composed of series of granites calcium-orogenic alkaline, while the muscovites, more enriched in $\mathrm{TiO}_{2}$, were considered of magmatic origin.
\end{abstract}

Keywords: magmatism peraluminous, biotite-muscovite-primary, system collisional.

\section{Resumo}

A Suite Cabeceira do Rio dos Bois, região de Mara Rosa-Nova Iguaçu (GO), constitui granitoides de composição granodiorítica e tonalítica, com caracteristicas peraluminosas, distinguidos como granodiorito VI, granodiorito MU e tonalito SJ, os quais alojam ocorrências auriferas. Sob o aspecto da geologia regional, esses corpos são intrusivos na Sequência de Santa Terezinha e correlacionam-se regionalmente, por meio de semelhanças petrográficas e geoquimicas com a Suite Aurmina. Essas rochas enquadram-se em um sistema colisional a pós-colisional, possivelmente relacionado à evolução do arco magmático eopaleoproterozoico. Estudos de litogeoquímica mostraram valores semelhantes de razões $\mathrm{MgO} / \mathrm{TiO}{ }_{2}$, sugerindo um "trend" evolutivo e aspecto de menor fracionamento dos elementos. Em termos de ambiente tectônico, essa suite representa magmatismo cálcio-alcalino com contaminação crustal ou granitos colisionais tipo A2, empobrecidos em Rb e Y. As principais alterações hidrotermais observadas foram biotitização, propilitização, sericitização e silicificação. Análises de químicas mineral de biotita e muscovita confirmaram gerações 
distintas dessas fases minerais, decorrentes das alterações hidrotermais. As biotitas primárias, sem reequilíbrio, têm composição de granitos da série cálcio-alcalinas orogênicas, enquanto as moscovitas, mais enriquecidas em $\mathrm{TiO}_{2}$, foram consideradas de origem magmática.

Palavras-chave: Magmatismo peraluminoso, biotita muscovita primária, sistema colisional

\section{INTRODUCTION}

The area selected for this study, called the Bois River Headwaters, located in the northwestern portion of the State of Goiás (Brazil), makes up part of the Campinorte Project, between latitudes S $14^{\circ} 03^{\prime}$ and $14^{\circ} 15^{\prime}$ and longitude W $49^{\circ} 12^{\prime}$ and $49^{\circ} 16^{\prime}$ (Figure 1 ) and represents around $75 \mathrm{~km}^{2}$. The access is facilitated by federal highway BR-153 (Belém-Brasília), for approximately $300 \mathrm{~km}^{2}$, or the highway Brasilia-Barro Alto-Uruaçu, both paved. The main towns in the area of research are Mara Rosa and Campinorte.

This work was part of the dissertation conducted at the University of Brasilia and proposes a revision in geological data, lithogeochemical and mineral chemistry. The following objectives guided the study: definition of the main granitic facies in the area, its spatial distribution and petrographic characterization and lithogeochemistry the granite host rocks of gold mineralization; study phyllosilicates major phases (biotite and muscovite) granite-related paragenesis. In this study, laboratory techniques were used such as petrographic analysis of transmitted and reflected light, which served for the selection of preferred fields to study mineral chemistry of phyllosilicates. This research was conducted at Microscopy Laboratory of the Institute of Geosciences (University of Brasilia).

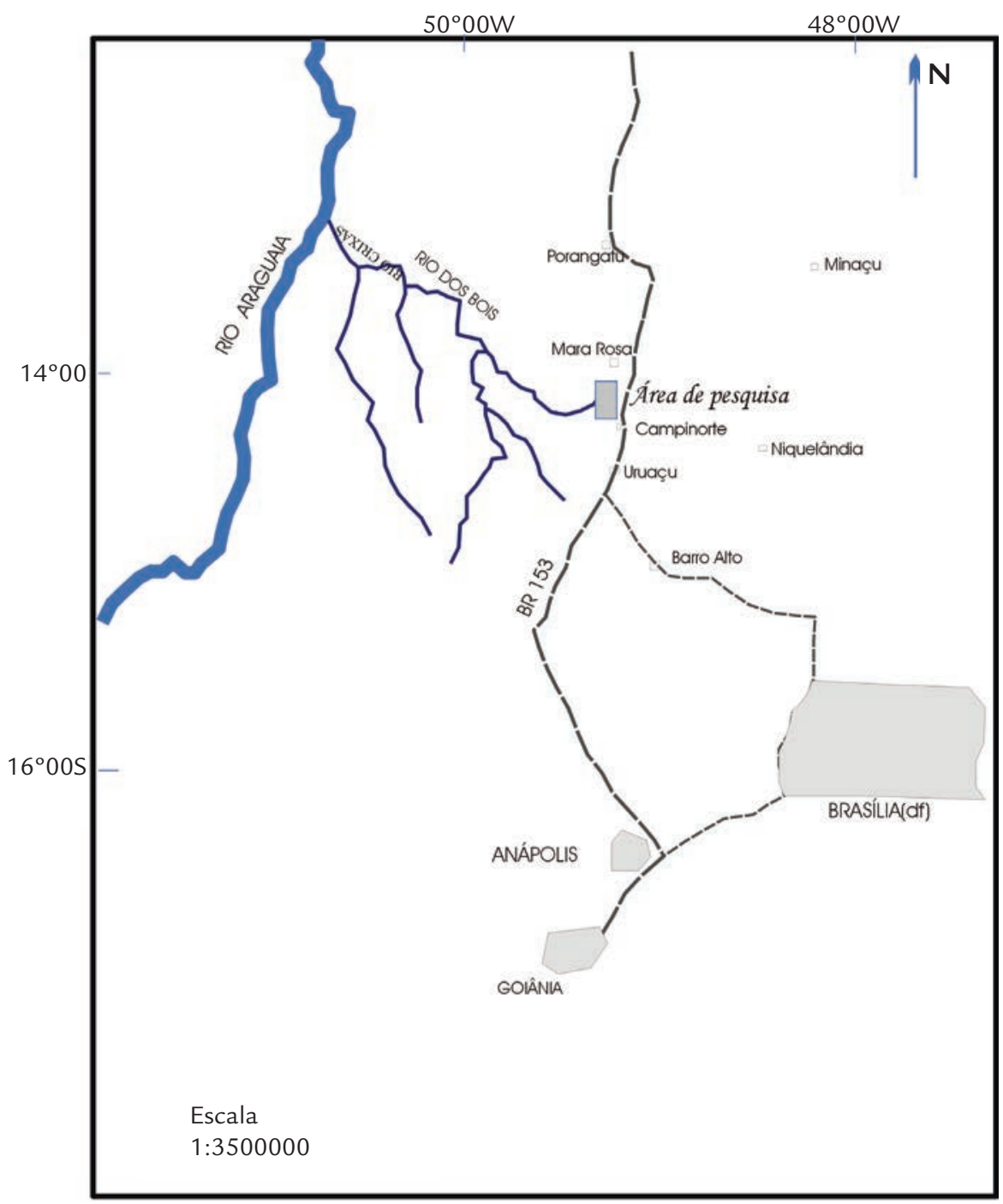

Figure 1

Location map of the study area. 


\section{GEOTECTONIC CONTEXT}

Within a focus of geotectonic search, the region is located in the central portion of the Tocantins Structural Province, whose tectonic partitioning for the eastern segment comprises: Cratonic cover, Brasília Belt, Goiás Massif and West Magmatic Arc of Goiás, as Figure 2.

The Brasília Belt occurs on the west border of the São Francisco Craton, and this tectonic entity is a member of the Brasiliano-Pan African orogenic system formed during the Neoproterozoic and comprising external and internal areas. The outer zone is composed of metasedimentary units that basically groups Paranoá, Canasta and formations Ibiá and Vazante, associations volcano-sedimentary, Ticunzal formation, Arai group, Serra da Mesa and tinny granites. These rocks overlap by reverse faults the group Bambui deposited east.

The inner zone consists of basement areas and the Group Araxá associated with allochthonous units, and its southern portion has a structure made by overlapping tectonic nappes with system Araxá-Canasta. Internally to Neoproterozoic mobile belt basement blocks occur mainly Archean, represented by Median Massif of Goiás, and the search area is located north of Hidrolina Block, possibly in the areas of contact between the median Massif of Goiás and the Arc Mara Rosa Magmatic.

The Median Goiás Massif is a complex association of rocks of various types, being interpreted as a high sialic basement in contact with mobile belt proterozoic (Marini et al. 1984), or as a complex collage of crustal fragments, including land pre- and Neoproterozoic Brasiliano areas (Fuck 1994). Comprises Archean greenstone-granite terrain, and volcano-sedimentary sequences.

The Goiás Magmatic Arc, exposed and defined in western Goiás, according to Pimentel \& Fuck (1992), covers ortognaissics paleoproterozoic terranes and volca-
Figure 2

Geotectonic map of the study area.

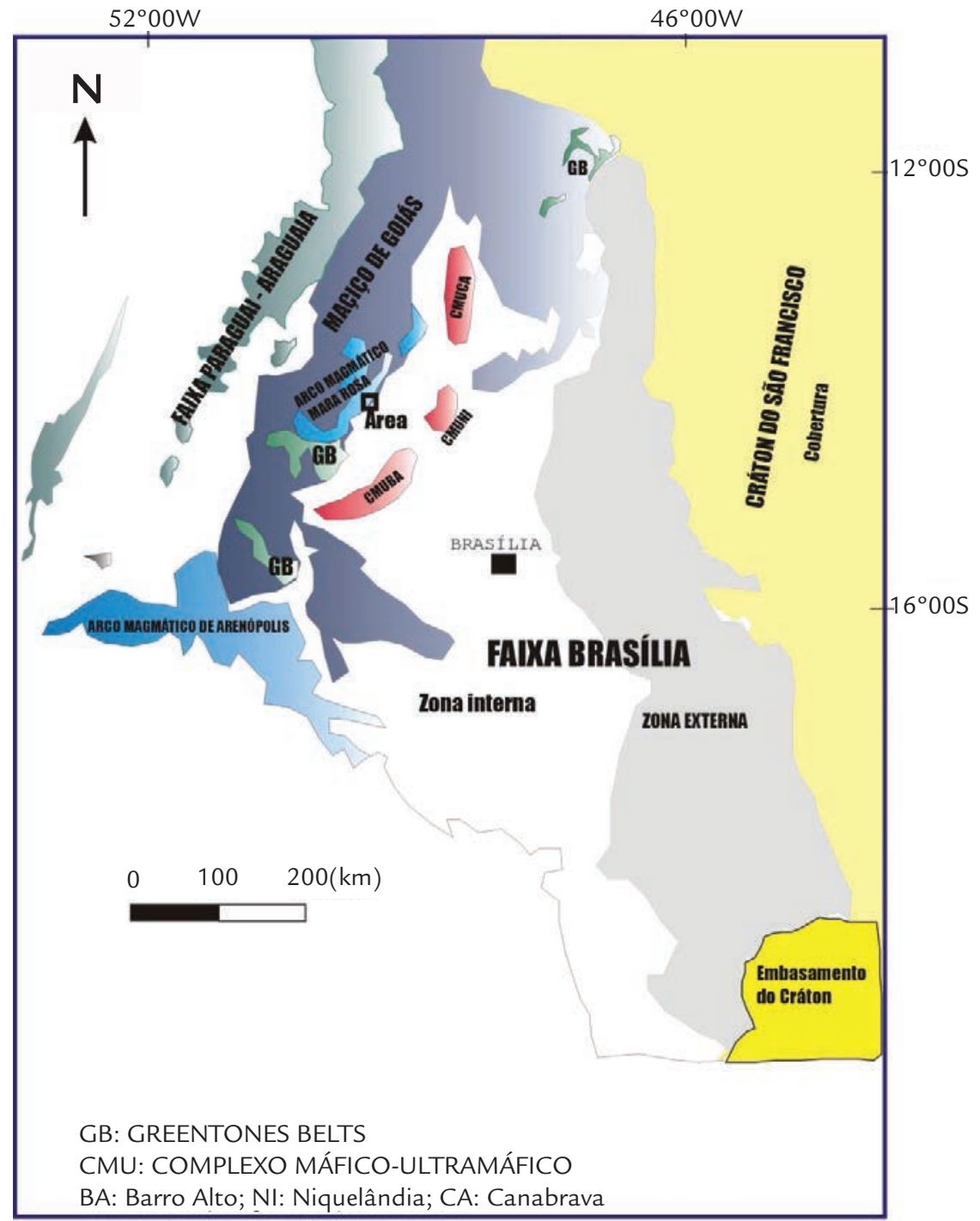


no-sedimentary sequences Neoproterozoic, deformed and metamorphosed in the amphibolite to greenschist facies. In regions Arenópolis, Israelândia and Sanclerlândia the magmatic arc is characterized by exposures of gneiss terrains orthoderivated with composition ranging from gabbro-dioritic to granodioritic. The volcano-sedimentary associations are represented by metavolcanic rocks ranging in composition from tholeiitic basalts to rhyolites.

\section{REGIONAL AND LOCAL GEOLOGY}

A summary of the regional geology was proposed by Abdallah (2001) and Abdallah and Botelho (2002), which was developed to integrate geological data (Figure 3)
These units are intruded by granitoid metamorphic late to post-orogenics.

The continuity of the magmatic arc of western Goiás northward is confirmed by the existence of metavolcanic rocks and Neoproterozoic metaplutonic old Rose in Mara region (Mara Rosa Magmatic Arc) with geochemical and isotopic signature similar to the west, suggesting the northern extension magmatic arc (Viana 1995).

based on field work by enforcement of regional geological profiles. Among the works that served as reference in this integration are mentioned: Kuyumjian (1994),

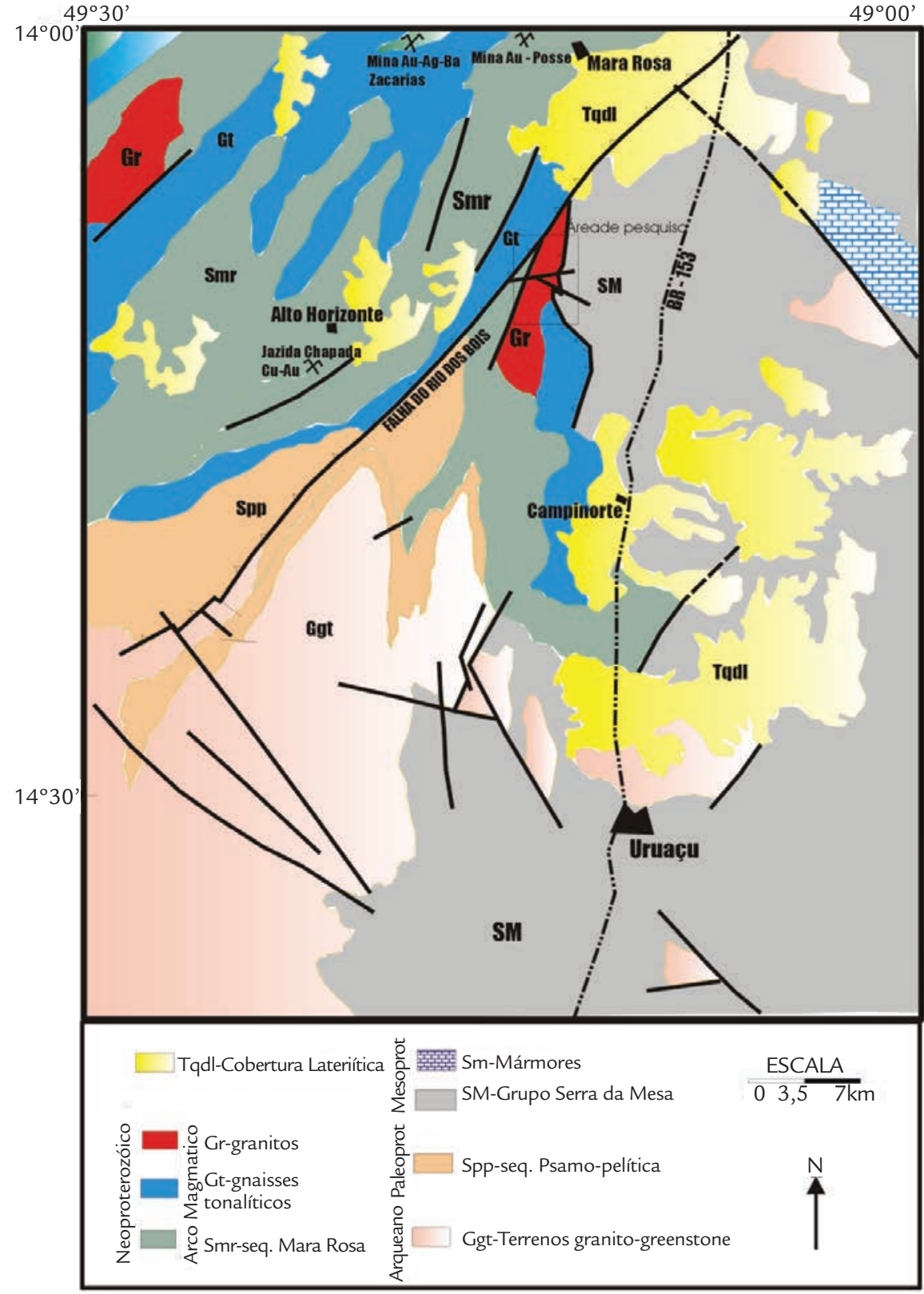

Figure 3

Regional geological map of the study area. 
Arantes et al. (1991), Silva \& Sá (1988), Ribeiro Filho (1981) and Lacerda (1986).

The main lithostratigraphic and chronostratigraphic units occurring within the Campinorte Project are: granite-greenstone terrain, psamo-pelitic (Santa Terezinha Sequence), Serra da Mesa Group, Mara Rosa Sequence and intrusive granites of the Rio dos Bois Suite, this last the object of this research.

Lithological associations with typical granite-greenstone terrains occupy a vast area of the southern portion of the Campinorte Project represented by Hidrolina Dome, which, according to the definition of Danni and Ribeiro (1978), constitutes portions of granitic basement of the Median Massif of Goiás. This set features regional distribution and lithologic homogeneity, becoming the leucocratic gneisses of granodioritic to tonalitic whose gneissic banding is defined by alternating levels of quartz-feldspathic and micaceous amphibolitic narrow bands, usually observed migmatitic features. In general, the metamorphism is amphibolite facies, although mineral parageneses indicative of granulite facies can be verified. In general the region Hidrolina is compartmentalized into three major structural domains: shear zone, granitic Hidrolina Dome and allochthonous fragments of Araxá Group, according to Kuyumjian et al. (2004).

The Santa Terezinha Sequence is a restricted portion midwest, especially among Campinorte and Nova Iguaçu city. In this region, the sequence consists of a set of supracrustal metasedimentary sequence, making tectonic contacts with rocks Hidrolina Dome and drive west of Mara Rosa Sequence. The main rocks of this sequence in the region are garnet-chlorite-muscovite schists, quartz muscovite schist, biotite schist and chlorite schist.

The Santa Terezinha Sequence represents the whole volcano-sedimentary low-grade metamorphic, located north of the city with the same name and located in the central portion of the Massif of Goiás This sequence has been correlated to the Mara Rosa Sequence, the Group Araxá and also as an integral part of the upper unit of land greenstone belts. Recently, this sequence was individualized as the unit being assigned to your Paleoproterozoic metamorphic set of low-grade metamorphic, predominantly psammitic and pelitic metasedimentary rocks. Subordinate, this sequence also contains felsic metavolcanic rocks and metaultramafic (Kuyumjian et al. 2004).

In the Serra da Mesa and Serra Dourada, north of Goiás, based on stratigraphic evidence, lithological and tectonic, Marini et al. (1977) proposed the name of Serra da Mesa Group to package metamorphic granitic massifs bordering the homonyms and mapped previously as Group Araxá. In the eastern area of work there is a set of predominantly metapsamitic rocks, metamorphic mapped initially as Group Araxá and later redefined as Serra da Mesa Group, probably mid-Proterozoic age. It is a set of quartz-mica schist, quartzite micaceous with abundant quartz veins, in the case of a metased- imentary sequence with subordinate carbonate contribution, as seen through the lenses of marble near the city of Campinorte. The contact with mylonitic granite is defined by extensive shear zones associated with thrust faults.

Specifically in the region of Mara Rosa, supracrustal units that constitute the volcano-sedimentary sequence are arranged in three main areas, structural directioned northeast and dips northwest, called band East, Central and West, according to Arantes et al. (1991). The eastern range was divided into four major stratigraphic units, from bottom to top: Amaro Leite Unit, comprised metagraywackes interlayered with mafic metatuffs; Araras Unit, metatuffs mafic to intermediate with interbedded metagraywackes, and felsic metavolcanic metacherts; Posse Unit, metatuffs felsic; and Carambolas Unit, composed of metatuffs sequence of mafic to felsic metavolcanic intercalations. All these rock types have undergone metamorphism that reached the amphibolite facies, which is the host of gold mineralization in the deposit Posse, the Posse felsic unit.

Small granitic intrusions, of approximately $2-3 \mathrm{~km}$ from the major axis, occur in the Bois River Headwaters, also intrusive in the volcano-sedimentary sequence of Mara Rosa and designated here Mundinho granite, Viuva granite and St. George granite, characterized as Bois River Suite, which are the subject of detailing. The local geology is represented in Figure 4, in which the main contacts, geological and structural features are presented. Three main lithologic assemblages distributed along the headboard of the Bois River designated metasedimentary sequence, volcanic-sedimentary sequence Mara Rosa and deformed granites were defined. Granite Viúva (type VI) is represented by a granite body of approximately 3 $\mathrm{km}^{2}$, quite hydrothermally altered and development of penetrative foliation marked by non-micaceous minerals. The Mundinho granite (type MU) constitutes a body of granite tectonite, an ellipsoid, flattened intrusive in a volcano-sedimentary sequence and variations in tectonic contact with quartzite and quartz muscovite schist. The features of mylonitization are quite pronounced in these granitoids, as feldspar porphyroblasts stretch and quartz, related to shear zone with north-south directions and development of foliation associated with sulphide and auriferous veins.

The granitic rocks of Bois River present $\mathrm{U}-\mathrm{Pb}$ ages ranging from 2179 to $2158 \mathrm{Ma}$, and there is no Archean contribution according Giustina (2007). The TDM Sm$\mathrm{Nd}$ model ages from supracrustal Campinorte Sequence and intrusive lithotypes of Bois River vary from 2682 to $2216 \mathrm{Ma}$, with mostly positive $\varepsilon \mathrm{Nd}$ values, which disclose the juvenile character of these rocks, in other words, the juvenile character with short crustal residence. The granodiorite yielded from zircon fractions revealed variably discordant compositions indicating an upper intercept age of $2173 \pm 10 \mathrm{Ma}$ (MSWD=0.54), interpreted as being representative of the igneous crys- 
tallization age. Zircon grains from metatonalite with five concordant zircon grains resulted in an upper intercept age of $2163 \pm 1 \mathrm{Ma}(\mathrm{MSWD}=0.76)$ which is also interpreted as the age of igneous crystallization. The mylonitic tonalite five spot analyses yielded a concordia age of $2158 \pm 8 \mathrm{Ma}(\mathrm{MSWD}=0.5)$, which is taken as the best estimate for the crystallization age of the igneous protolith.

Geocronologic regional works dating U-Pb in zircon of metagranite associated with supracrustals provides a value of $2175 \pm 12 \mathrm{Ma}$ for igneous crystallization (Pimentel et al. 1997). Isotopic analyzes result in Sm-Nd model ages
(TDM) into metagranitics rocks between 2.52 and $2.3 \mathrm{Ga}$ and positive $\varepsilon N d$ (Kuyumjian et al. 2004), which thus indicates the juvenile character of short crustal residence for sequence Campinorte and associated metagranitics. The data presented by Giustina (2007) is similar to other Paleoproterozoic Provinces described in the Brasília Belt, but it contrasts with negative $\varepsilon_{\mathrm{Nd}}$ values in granitoids of west border and Serrinha Blocks of San Francisco Craton, in the same age, which have features of material with long residency and crustal contamination; hence, this study contributes to the reconstruction of the Columbia supercontinent (Abdallah 2011).

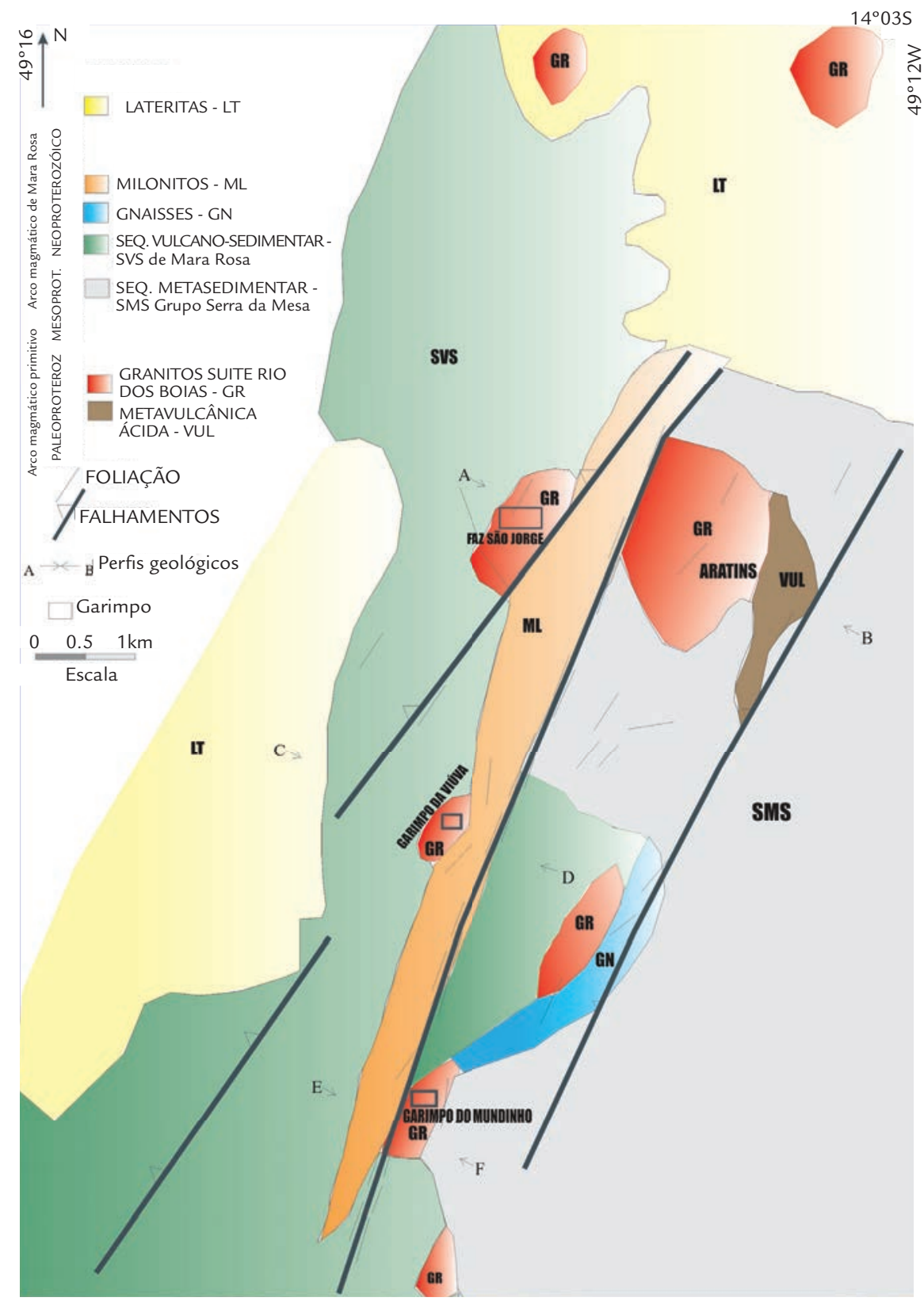

Figure 4

Geological map location of the study area. 


\section{PETROGRAPHIC FEATURE OF SUITE OF BOIS RIVER}

In this section we present the main petrographic types, the most representative of the studied granites, and textural and mineralogical aspects of the rocks, which were summarized in the facies of hydrothermal processes preserved, and which has in biotite and muscovite granite paragenesis. Thus, it comes down to biotite muscovite peraluminous tonalite SJ, albitizated tonalite SJ, biotite muscovite granodiorite VI (biotite rebalanced), and muscovite biotite granodiorite $\mathrm{MU}$ (magmatic muscovite and biotite).

The tonalite SJ predominates muscovite and biotite which was possible to characterize three types petrographic whose primary composition varies in function of intensity of hydrothermal alteration, as albitization, sericitization (potassic alteration), biotitization and propylitic (propylitic alteration), designated informally as Gc, Gb and Ga, with variations in mineralogical composition in function the stage of the hydrothermal alteration and the amount of secondary minerals.

The first type, Gc, is a metatonalite (samples $111 \mathrm{C}$ and 111C1), comprises macroscopically a rock with granolepidoblastic texture, coarse grained and foliation marked by biotite lamellae orientation. Feldspars exhibit tabular habit and oval form and reach up to $1.5 \mathrm{~cm}$ in diameter and is surrounded by biotite. Microscopically, it is composed of the following mineral phases, quartz, albite, biotite, and zoizite, titanite, chlorite, tourmaline and opaque include between magnetite and pyrite (Figures 5A and 5B). The predominant feldspar is albite $(\mathrm{Ab} 100 \%)$ and generally presents with anhedric forms, with frequent mantle around the recrystallized quartz mineral and rarely presenting twinning according to the albite law preserved. As the main product change, occurs the formation of white mica and epidote. The masses of quartz is anhedral crystals with ondulation extinction and polygons contacts, biotite form plates throughout with brown coloration (Figure 5B), which may be completely chlorized. In small amounts, it is observed pyrite usually with a halo of alteration to limonite, and traces of magnetite, as products of hydrothermal alteration. The titanite may have navicular habit, but in general it is anhedric shaped, brownish color and frequently associated with aggregates of biotite and epidote.
Another type petrographic, Gb (samples 111B and 111B1), it is metatonalite, probably a more altered facies observed in this area. It corresponds to a rock of light gray, medium grained presenting an incipient banding. The mineralogy is mainly represented by more altered feldspar, mainly albite, and quartz and actinolite. This rock has disseminations of sulphides as pyrite and chalcopyrite, and pyrite displays euhedric shapes and coloformic.

The sample Ga is biotite muscovite metatonalite (samples $111 \mathrm{~A} 2$ and $\mathrm{A} 3$ ) that have under microscopy presents inequigranular texture, medium to coarse grained and grayish white. It develops discrete foliation marked by micaceous minerals, mainly biotite. Sample is less deformed among the other rock types granite. The mineralogy consists of plagioclase (albite), K-feldspar, biotite, white mica, epidote, quartz and magnetite (dashes). Petrographically characterized by higher amounts of white mica, generated by intense sericitization which was submitted and the modal proportion of biotite subordinate. The latter are presented as isolated plates with pleochroism brown tint and represent remains of magmatic biotite. The feldspars have become quite sericitized.

In the body biotite muscovite granodiorite VI were characterized petrographic types that host gold mineralization and variations are hydrothermally-altered granodiorite, with deformation features developed, as can be seen in Figures 6A to $6 \mathrm{D}$. Basically, this body hydrothermally granodiorite VI hosts auriferous veins showing variations in the relative intensity of hydrothermal alteration.

The sample VIA, muscovite biotite granodiorite cataclastic, corresponds to grayish rock, coarse to medium grained texture and granolepdoblastic foliation marked by the preferred orientation of micaceous minerals. The mineralogy essentially comprises albite, $\mathrm{K}$ feldspar, biotite, white mica, epidote, and in proportions subordinated, there is ilmenite and pyrite, and tourmaline, zircon and titanite as accessories. The plagioclase is mainly albite (Ab 100\%), showing xenomorfic habit with oval form, often showing albite twinning law. The fenoclasts feature heavily stretched and rotated (Figure 6D) usually surrounded by a mantle of change consists of white mica, quartz and epidote or only with halo of recrystallized quartz. The quartz grains present

\section{Figures 5}

Petrographic aspects of biotite muscovite metatonalite SJ (Gc): in (A) textural relationship between crystals of albite, quartz and secondary biotite, and in

(B) detail of plates secondary hydrothermal biotite and epidote aggregates; acronym Kretz (1983) minerals, biotite

(Bt), muscovite (Ms), quartz (Qtz), plagioclase $(\mathrm{Pl})$.
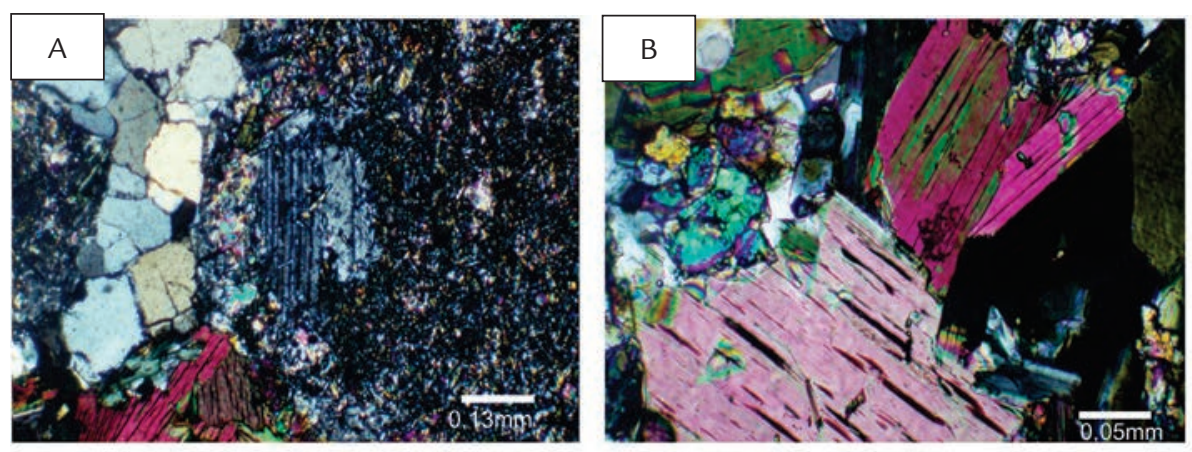

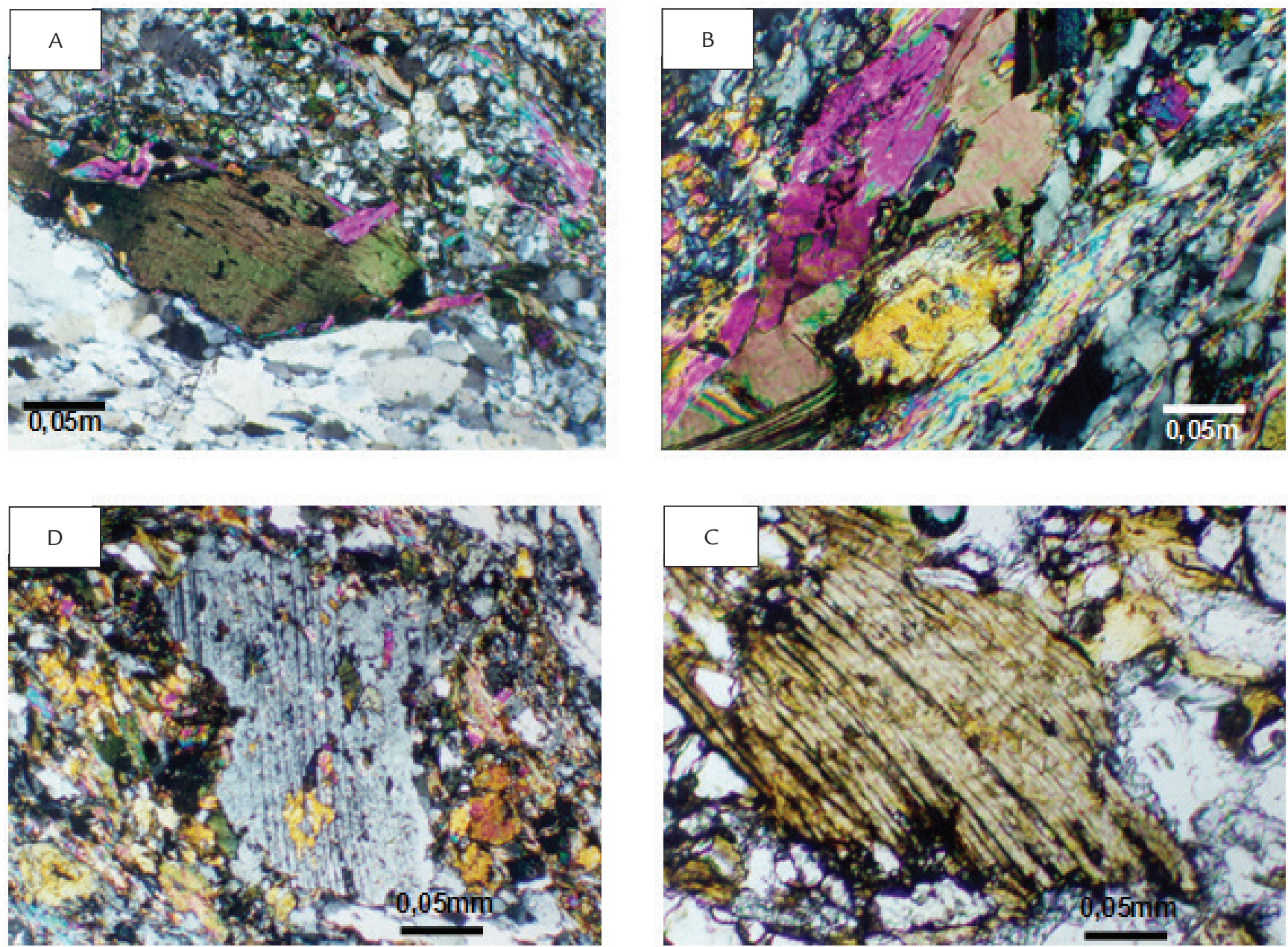

Figures 6

Biotite muscovite Granodiorite VI. In (A and B) aspects of biotite rebalanced, type 2 , granodiorite protomilonitic feature oriented lamellae associated with muscovite, quartz and armored in lamellae well developed; in (C) with biotite primary magmatic features, characteristics presented as the more brownish pleochroism typical of magmatic biotite; and in (D) fenoclast twining of albite and showing deformation features.

in this lithotype are xenomorfics habit, heterogeneity in size and exhibit wavy extinction, with contacts polygon. The biotite shows up as plates or lamellae well developed, primary type rebalanced (Figure 6B), with brown pleochroism, and occurs associated with hydrothermal white mica and epidote aggregates; often these minerals form shear bands marked by irregular and narrow bands, where they alternate with bands mainly composed of recrystallized quartz.

In type VI4A1 it constitutes variation from the previous sample, and also checked deformation and hydrotermal effects, with higher modal proportion of biotite and titanite. Aplitic dikes are observed in sectioning this lithofacies where lodges by gold-bearing quartz vein, always with substantial amount of chlorite. The sample VIVI represents a coarse-grained to pegmatoid biotite granodiorite texture inequigranular with reddish due to weathering, and presents features of cataclasis as fractured feldspars and drawn according to a foliation of biotite primary rebalanced (Figure 6C), and twinned twinning twisted. This sample is granitic texture with better preserved.

The lithofacies granodiorite are represented by sample 53C, designated biotite muscovite granodiorite MU, the more preserved lithofacies, with both primary and magmatic biotite. This is characterized by strongly stretched porphyroclasts of feldspar and quartz surrounded by alteration mantle of quartz (fine aggregates), epidotes and white mica. The essential mineralogy comprises phenocrysts of feldspar (microcline) and plagioclase (albite), the latter in greater quantity, and 
white mica, biotite and epidote. Magnetite and pyrite occurs in trace amounts. Micas occur as isolated lamellae (biotite) or as oriented aggregates of white mica (muscovite). Furthermore occurs subordinate amounts of carbonate (greater than $90 \%$ percent weight by calcite) (Figure 7B).

In the facies biotite granodiorite mylonitic MU, sample SA5A, rock is light gray, very altered/hydrotermal effects, with millimeter strips of dark gray coloration consisting primarily of biotite and muscovite (biotite foliated), featuring a prominent foliation. We highlight some aspects mineralogical as chloritization of biotite and quite common the presence of alteration minerals such as calcite carbonate. The chlorite shows lamellar habit or form aggregates of thin lamellae with pleochroism ranging from light green to colorless and presenting anomalous interference color. It is observed in this rock the presence of relict material mylonitic granite (Figure 7 ).
Figures 7

Granodiorite MU hydrothermal facies; In (A) secondary magnesian biotite, biotite type 3, thinner lamellae in hydrothermal paragenesis associated with carbonate, quartz and chlorite and sulphides; and in (B) textural aspect of muscovites dispersed in granite.
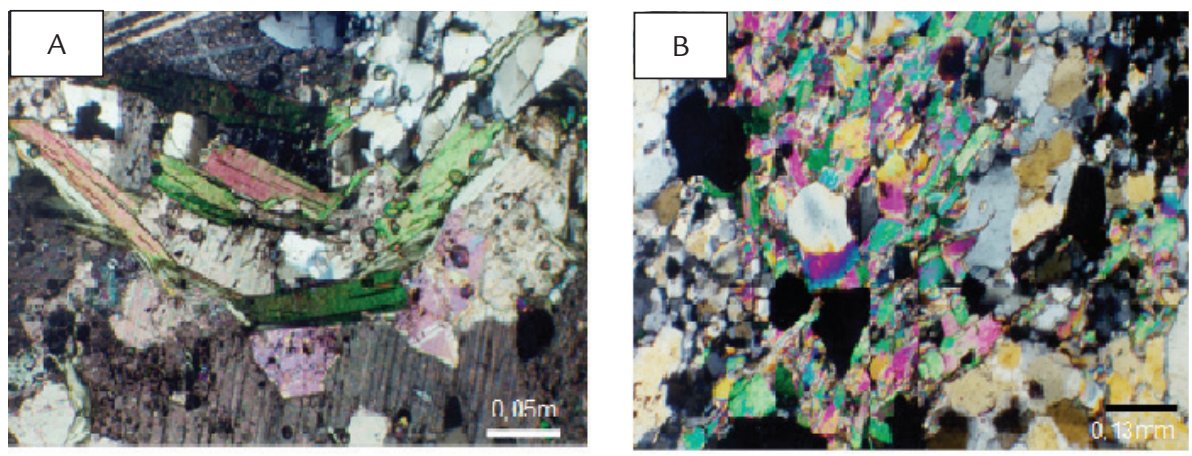

\section{MINERAL CHEMISTRY}

This topic studies, through mineral chemistry, the major phases of phyllosilicates observed in granitic rocks, mainly biotite and muscovite. The chemical analyzes were made using electronic microprobe, Cameca SX$50^{\circledR}$ model, in the Laboratory of Electron microprobe of the University of Brasília. Preliminarily, we performed a study and a petrographic analysis of the optical prop-

\subsection{Biotite}

The study of the chemical composition of biotite formed auxiliary tool in the definition and characterization of the granitic rocks in the region of research. The ferromagnesian mineral primary, often in the composition of granitic rocks, so with distinction, reflects the nature and physicochemical conditions of this magma. Metasomatic-hydrothermal conditions in the presence of biotite can be characterized a zone of enrichment potassium granite or potassium alteration.

The micaceous mineral is biotite with trioctahedral structure, with the general formula $\mathrm{X}_{2} \mathrm{Y}_{6} \mathrm{Z}_{8}(\mathrm{OH})_{4}$ in which $\mathrm{X}=\mathrm{K}, \mathrm{Na}, \mathrm{Ca} ; \mathrm{Y}=\mathrm{Fe}^{+2}, \mathrm{Mg}, \mathrm{Mn}, \mathrm{Li}, \mathrm{Fe}^{+3}, \mathrm{Al}, \mathrm{Ti}^{+4} ; \mathrm{Z}=\mathrm{Si}^{+4}, \mathrm{Al}$. Basically we analyzed the major elements in the form of oxides. How stands the chemical composition of magmatic biotite are diagnostic of the types of magmas generated from different sources and different petrogenetic histories, according to Nachit (1986) and Abdel-Rahman (1994).

The biotite from two mica granites studied usually occurs in the form of lamellae and has preserved when brown coloration brownish, and are common in transformation to chlorite (chloritic). In the diagram proposed by Nachit (1986) for different types of biotite granitic rocks (Figure 8), where the vertices are $10 \mathrm{TiO}_{2}, \mathrm{FeO}+\mathrm{MnO}$ and $\mathrm{MgO}$, we define the primary fields of brown biotite, biotite domain erties of minerals and separation fields preferred for chemical analysis.

Most of these minerals have significant compositional variations, i.e. rebalancing physicochemical related to hydrothermal processes that have acted on the granitic rocks. Especially phases micaceous white mica and biotite, as well as albite and chlorite, which are relatively abundant in hydrothermal granites VI MU and SJ types.

of primary rebalanced green-brown and finally the field of secondary biotite of green.

The three types of biotite granites can be identified in the study: biotite I, primary found in biotite muscovite metagranodiorite $\mathrm{MU}$, variety richer in $\mathrm{TiO}_{2}$; biotite type II primary rebalanced in an intermediate position, identified in SJ metatonalite biotite muscovite, biotite muscovite granodiorite VI and biotite granodiorite VI. Biotite is nearer to the secondary type III, in a more advanced stage of hydrothermal transformation identified in biotite muscovite $\mathrm{SJ}$ and biotite muscovite MU hydrothermalized, and only the primary biotite can be used for the granites tipology. The recognition of these different biotite phases constitutes essential point in the development of this study.

The replacement of $\mathrm{Ti}$ in octahedral sites has been studied in biotite metamorphic having consensus in the literature that the content of $\mathrm{Ti}$ in biotite increases with metamorphic grade, i.e. with increasing of temperature. The decrease in $\mathrm{Ti}$ studied biotite is related to hydrothermal processes that acted on granitic rocks area, so that titanium was extracted from the structure of biotite rich in titanium by these hydrothermal solutions and crystallization as a new mineral phase rich in titanium as titanite and/or rutile and/or ilmenite. 


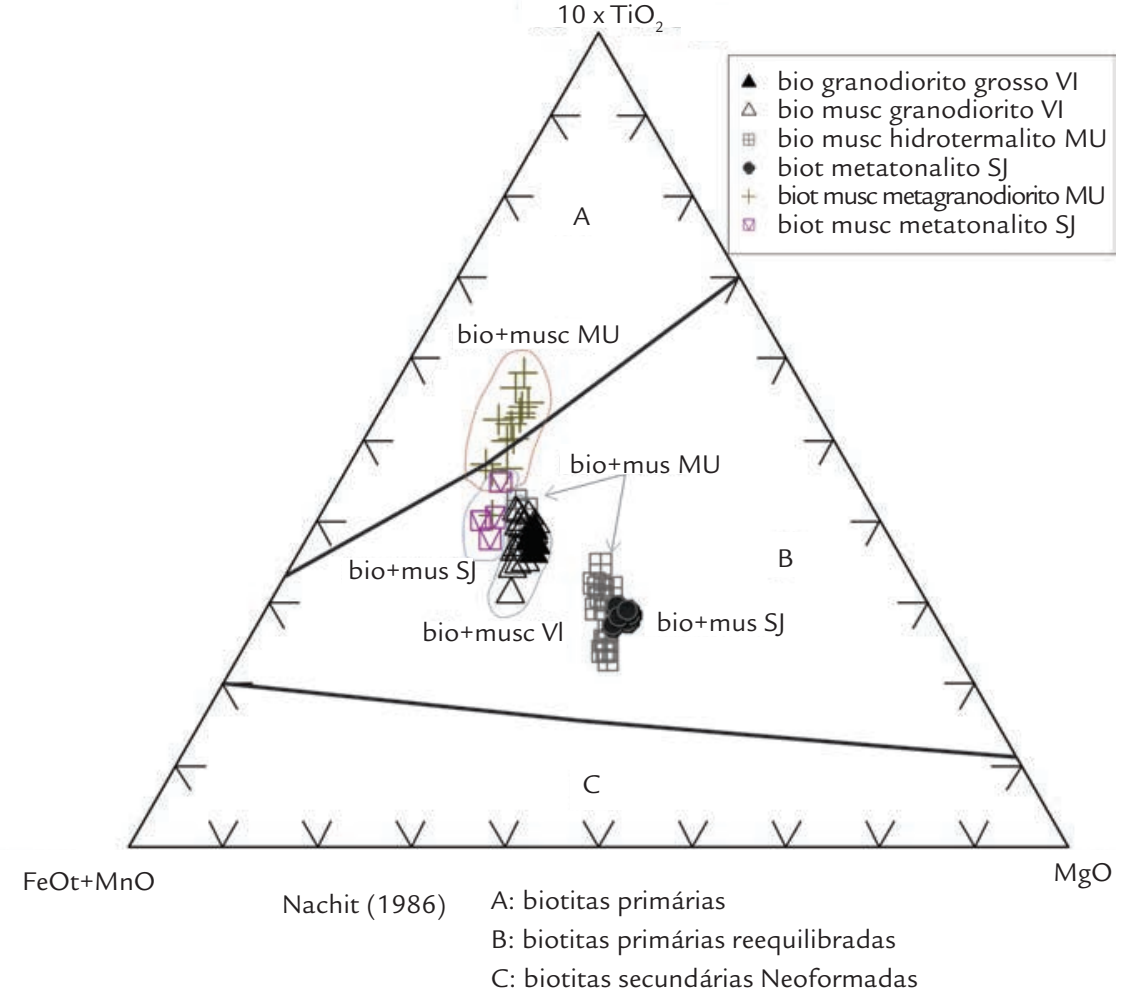

Figure 8

Graphic ternary (Nachit 1986), which visualizes the three types of biotite granites found in the Bois River Suite. Granodiorite VI (biotite type B, rebalanced), granodiorite $\mathrm{MU}$ (primary and secondary biotite), metatonalite SJ (biotite rebalanced primary and secondary), total $n=67$ analyzes.
In the diagram of classification of biotite from Deer et al. (1992 - Figure 9), where the poles are positioned trioctaedrics non-litiniferas micas, it can be distinguished fields of biotites and phlogopites, and the iron rich series annite-siderophyllite and magnesian series phlogopite-estonite.

From the Figure 9 it is characterized that three types of biotite was designated types I, II, III, related to the phases of development of this granitic magmatism. The biotite type I observed in samples $53 \mathrm{C}$ and $111 \mathrm{~A} 2$ represents the primary biotite in granodiorite MU and tonalite SJ, whose analyzes are concentrated in the field iron richest biotite of annite-siderophyllite series. The biotite type II, primary rebalanced, observed in muscovite biotite granodiorite VI, is located in the field of biotite Fe richer, but concentrated on the intermediate portions between annite and phlogopite, and have brown coloring and lamellar habit.

The biotite type III, near to the secondary field, belongs to the phlogopite-estonite series forming trioctaedrics micas more enriched in $\mathrm{MgO}$. It is often associated with films biotites foliated (granodiorite MU) or as disseminated plates in metatonalite SJ, samples 111C. It presents brownish coloring tending to greenish to colorless pleochroism and found often chlorited associated with sulfides mainly pyrite and chalcopyrite. These variations in the composition of biotite can be seen in the graph $\mathrm{TiO}_{2} \mathrm{x}$ $\mathrm{MgO}$ (Figure 10), in which the type III biotite is typically depleted in $\mathrm{TiO}_{2}$ and typically more magnesian biotite in relation to types I and II.
The study of the chemistry of primary biotite granitic rocks have been used for classification into different types of associations or magma magmatic series according to Nachit (1986). The positioning of the biotite in diagram $\mathrm{Mg} v s . \mathrm{Al}$ (afu is atom per formula unit) proposed (Figure 11), in which can be distinguished different groups of magmatic biotite, based on the relationship between cationic $\mathrm{Mg}$ and $\mathrm{Al}$, is both in the field of alumino-potassic high $\mathrm{MgO}$ granitic series (biotite II, primary rebalanced), as the field of calc-alkaline series (biotite I, primary). Note that the biotite rebalanced should be interpreted with caution in this diagram, considering that the biotite II clearly had an enrichment of aluminum, moving into the alumino-potassic domain.

Abdel-Rahman (1994), using a database containing 325 analyzes biotite granite of the various locations, showed that the composition of biotite depends on the nature of the magma from which crystallized, and on the types of granitic suites including alkaline anarogenic suite type $\mathrm{A}$, calcium alkaline orogenic suite type $\mathrm{C}$ and peraluminous suite type $\mathrm{P}$.

In the ternary diagram $\mathrm{MgO} \times \mathrm{FeO} \times \mathrm{Al}_{2} \mathrm{O}_{3}$ (Figure 12), it appears that the investigated biotite granites field concentrates on the calcium alkaline series (type C), in the case of primary biotite I of granodiorite MU and granodiorite VI, it was also confirmed in the diagram of Nachit (1986) the calcium alkaline character. Others biotite tend to field peraluminous series as samples of tonalite SJ, showing that there was a rebalancing effectively with enrichment in aluminum, positioning them in the field peraluminous domain. 
Figure 9

Classification of biotite of the search area, according to Deer et al. (1992), where we highlight two distinct groups:

biotite series annite-siderophyllite enriched in Fe characterized in granodiorite $\mathrm{VI}$ and granodiorite $\mathrm{MU}$; magnesian biotite of phlogopite-estonite series (magnesian biotite) typically rebalanced found in the granodiorite $\mathrm{MU}$ and metatonalite SJ, on the more hydrothermalized portion associated of late alteration minerals.

Figure 10

Diagram $\mathrm{MgO}$ vs. $\mathrm{TiO}_{2}$ for the biotite of granite Bois River Suite, demonstrating enrichment in $\mathrm{MgO}$ and $\mathrm{TiO}_{2}$ decrease in the magnesian biotite near to secondary phlogopites mica in both the granodiorite $\mathrm{MU}$ and metatonalite $\mathrm{S}$.
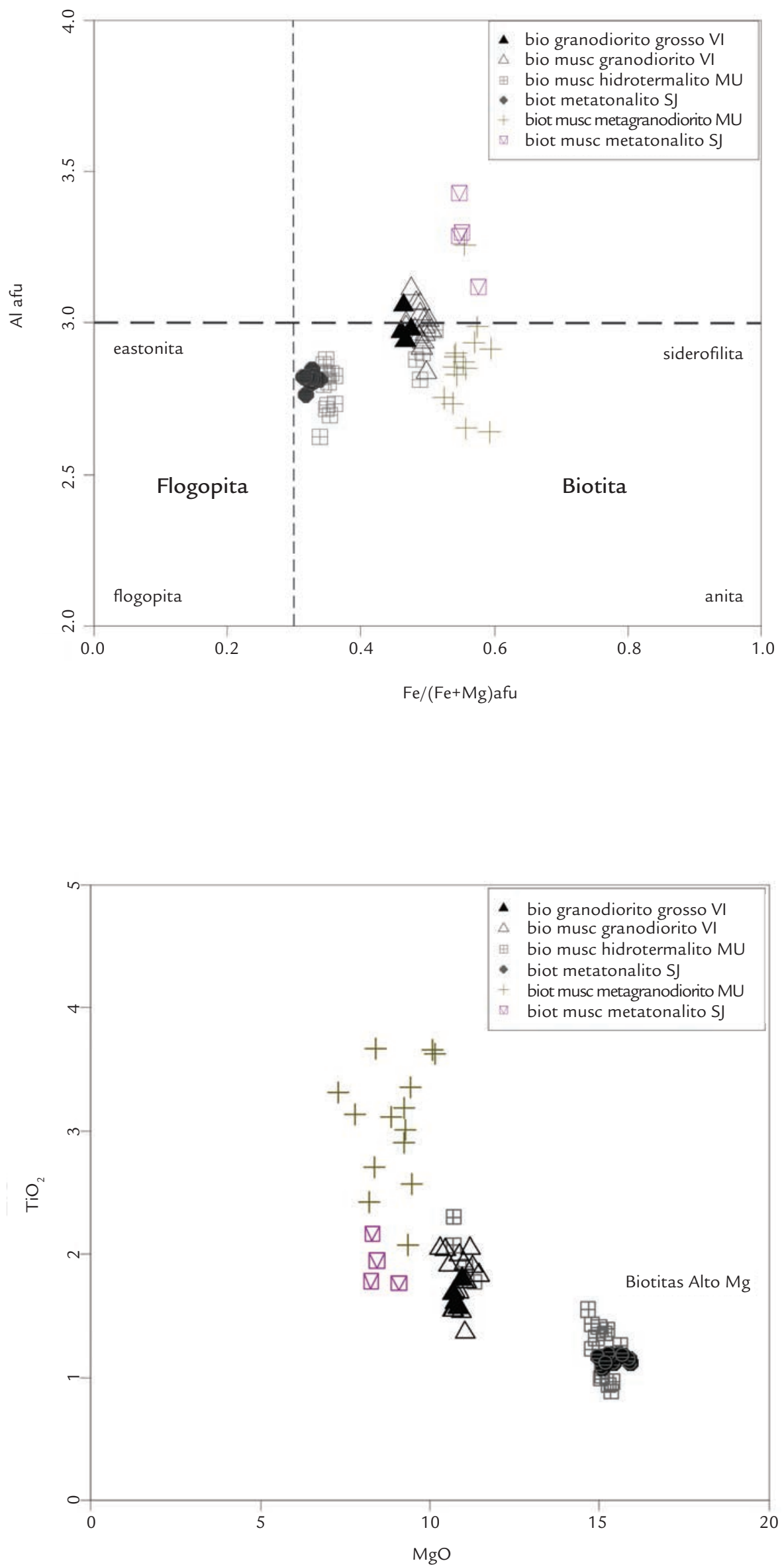

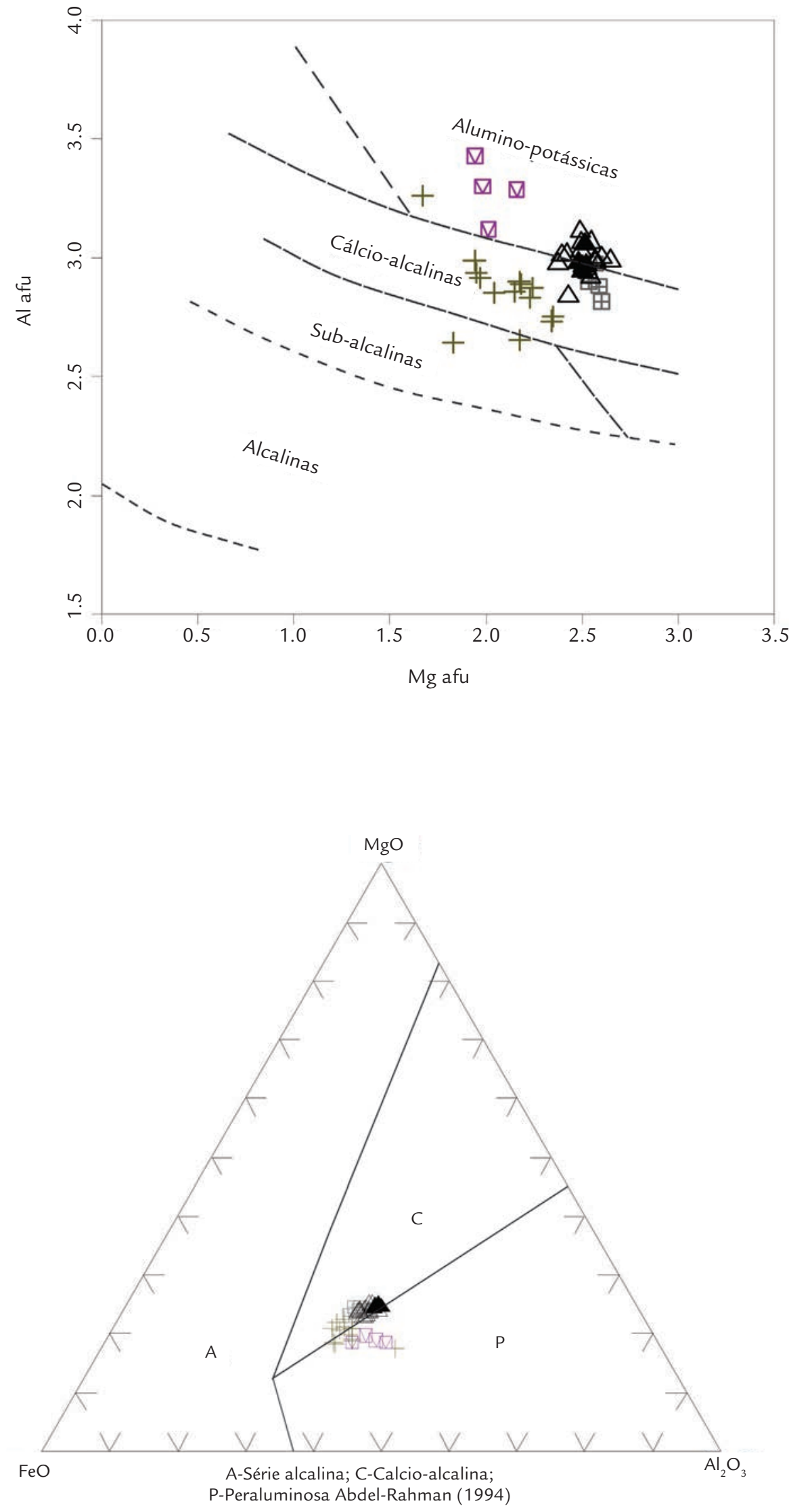

Figure 11

Distribution of the biotite Bois River Suite according to the magmatic series of Nachit (1986), with the primary biotite calc-alkaline series in granodiorite $\mathrm{MU}$, the biotite granodiorite $\mathrm{VI}$ and tonalite $\mathrm{SJ}$ are located in the area alumino-potassic; legend as previous.
Figure 12

Diagram ternary $\mathrm{MgO} \times \mathrm{FeO} \times \mathrm{Al}_{2} \mathrm{O}_{3}$ according to Abdel-Rahman (1994) for biotite of the Bois River granites, where the primary biotite granodiorite type MU positioned preferably in the field of calc-alkaline series, legend as previous. 


\subsection{Muscovite}

The muscovite mica represents important mineral phase in the paragenesis of granitic rocks and also geological significance in the context of the mineralized areas, designated generally as white mica. The investigations led to distinguishing different types of white mica, textural differences being observed as well-developed lamellae or also in the form of aggregates of fine lamellae. Regardless of habit, the pleochroism can vary from colorless to slightly pale.

Based on the ternary diagram represented by poles, $\mathrm{Al}, \mathrm{M}^{+2}(\mathrm{Fe}+\mathrm{Mn}+\mathrm{Mg})$ and $\mathrm{Si}$ (Figure 13), which defines the extremes of mica white as a solid solution consisting by muscovite and celadonite according to the classification of Rieder et al. (1998). Micas analyzed are located near the pole of phengite and can be classified as muscovite-phengite, both the primary and the secondary.

The incorporation of $\mathrm{Ti}$ in the structure of dioctaedrics micas has been widely used to study the evolution of granites. An important conclusion from this study refers to increasing the titanium solubility with increasing of the grade metamorphic, i.e. of the temperature (Monier and Robert 1986). Muscovites in the two-mica granites, Ti has been used to distinguish magmatic muscovites of the muscovites post-magmatic or late, the first typically more enriched in titanium, due to the greater availability of $\mathrm{Ti}$ in the early stag- es of crystallization. Such that the more enriched micas may occur either in metamorphic rocks such as in granitic rocks.

Based on Figure $14 \mathrm{Al}_{2} \mathrm{O}_{3} \times \mathrm{TiO}_{2}$ boundary between primary and secondary muscovite corresponds to around of $0.6 \% \mathrm{TiO}_{2}$, from which we can characterize three types of muscovites designated I, II and III, type II intermediate between I and III.

The muscovite type I corresponds to the typical primary magmatic phase, occurring mainly granodiorite $\mathrm{MU}$, appearing as aggregates of plates in paragenesis with magmatic biotite. The muscovite type II, intermediate between the two types of $\mathrm{TiO}_{2}$, has values between 0.4 and $0.6 \%$, occurs predominantly granodiorite VI in the form of lamellar, aggregates oriented phengite and represents an intermediate stage in the evolution of hydrothermal sometimes in paragenesis primary biotite rebalanced.

The type III represents fengites aluminous compared to other, occurs in the form of thin lamellar masses and characterized by lower values of $\mathrm{TiO}^{2}$, forming white mica hydrothermal example, both the tonalite SJ (in paragenesis with magnesian biotite), as well as granodiorite VI. Indistinctly, muscovite varieties have significant values between 0.3 and $0.6 \% \mathrm{BaO}$, not finding correspondence with other types of muscovite in the literature.
Figure 13

Classification of white mica, according to Rieder et al. (1998), for the granites of the Bois River Suite. The white mica is phengite type, focusing on the pole in the muscovite-phengite series, both the primary and the secondary. Total analysis $\mathrm{n}=100$.

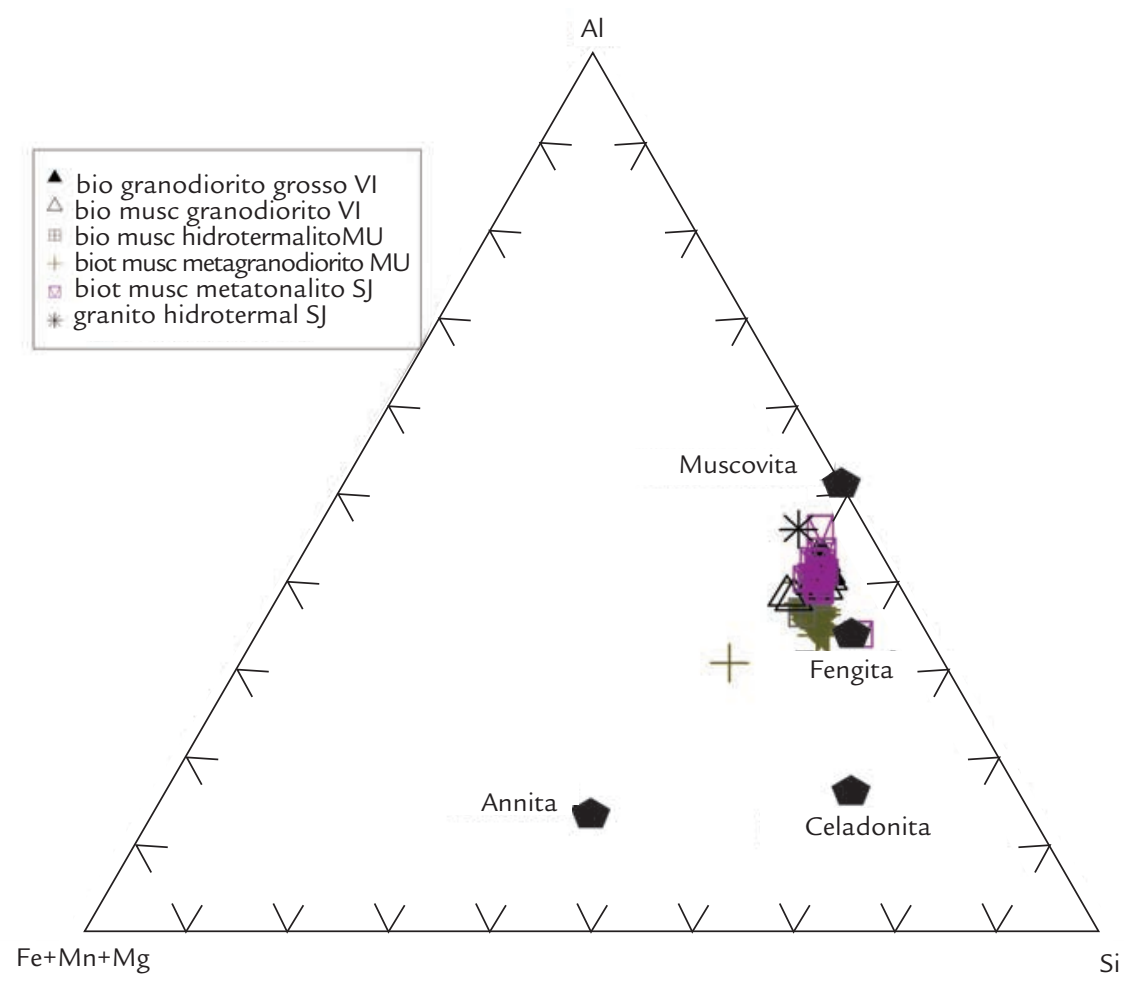




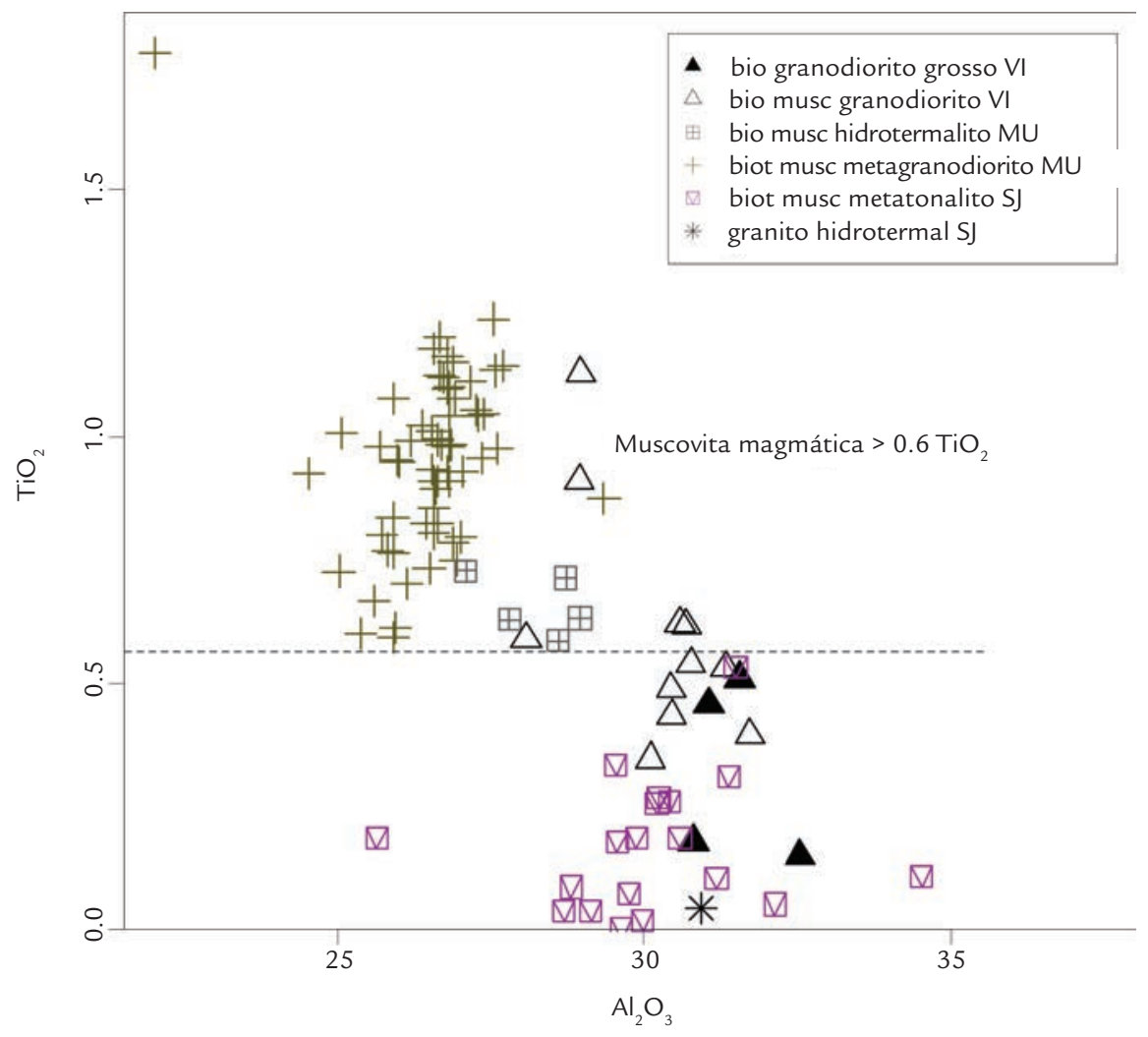

Figure 14

Diagram $\mathrm{TiO}_{2} \times \mathrm{Al}_{2} \mathrm{O}_{3}$ of muscovites (fengite) granites studied, the boundary between the two main types I and II, is close to $0.6 \% \mathrm{TiO}_{2}$.

\section{LITHOGEOCHEMISTRY}

The lithogeochemistry study aimed to characterize the chemistry of the granitic Bois River Suite, host of gold mineralization, through the analysis of major elements, trace elements and rare earth elements. Note that the selection of granite types for analysis was to test the petrography, which were less altered and hydrothermalized. The chemical analyzes were performed at the Laboratory Bondar-Clegg, Canada, the major elements by X-ray Fluorescence (XRF) and trace elements analyzed by neutron activation (INAA).

The chemical composition of the rocks will be used in order to establish criteria to diagnose the type of original granite, since in petrography, the studied rocks were subjected to hydrothermal and metasomatic processes from highest to lowest intensity. However, the performance of metasomatic processes implies that the geochemical characteristics of these documents have changed, especially in relation to mobile elements. Given these observations, the geochemical compositions will be used in a qualitative manner, especially in an attempt to identify the composition of granites and tectonic environment. The samples selected for analysis in general do not present the effects of weathering and represent granitic types most characteristic of each lithofacies. The results of chemical analyzes performed are presented in tables, which we used for the preparation of diagrams petrochemicals.

The rocks studied were classified using the diagram Debon and Lefort (1983), which uses the parameters P and $\mathrm{Q}$ (Figure 15), to indicate the tonalitic granodioritic composition. In granodiorites VI and MU predominates granodioritic in composition and only tonalitic in type SJ. Three samples were positioned outside of the petrographic fields, being those most hydrothermalized. This diagram was preferred naming regarding classic petrographic classification due to mineralogical transformations suffered by these granites.

For geochemical study of the granites were used variation diagrams of major oxides and trace elements, in order to describe the behavior and evolution of these granites. In the diagram $\mathrm{MgO} \times \mathrm{TiO}_{2}$ (Figure 16), there is similarity between the ratio $\mathrm{MgO} / \mathrm{TiO}_{2}$ of the samples despite hydrothermal alteration developed, i.e., these elements were not significantly modified in relation to magmatic concentrations. The rocks analyzed show an evolution of the less evolved granitic to terms with little $\mathrm{MgO}$ and $\mathrm{TiO}_{2}$ in chemical composition.

In binary type Harker diagrams showing variations of the different oxides in relation to the silica for the granites of Bois River Suite, the content of $\mathrm{SiO}^{2}$ ranges from 57 to $81 \%$, the one of $\mathrm{Al}_{2} \mathrm{O}_{3}$, from 10 to $16 \%$, the one of $\mathrm{K}_{2} \mathrm{O}$, from 0.2 to $3.0 \%$, the one of $\mathrm{Na}_{2} \mathrm{O}$, from 2.2 to $4.7 \%$, the one of $\mathrm{CaO}$, between 0.3 to $3 \%$, the ratio of $\mathrm{K}_{2} \mathrm{O} / \mathrm{Na}_{2} \mathrm{O}$ is lower than 1 , and the ration of $\mathrm{MgO} / \mathrm{TiO}_{2}$ ranges from 2 to $7 \%$. Additionally, it is shown a negative correlation between silica and $\mathrm{CaO}, \mathrm{TiO}_{2}, \mathrm{MgO}, \mathrm{P}_{2} \mathrm{O}_{5}$, with a trend of increasing $\mathrm{Na}_{2} \mathrm{O}$ with silica, while the relationship with $\mathrm{K}_{2} \mathrm{O}$ shows a more random distribution. Thus, in terms of which is richer in silica, there has been a decrease of $\mathrm{Ti}, \mathrm{Mg}, \mathrm{Ca}$ and $\mathrm{P}_{2} \mathrm{O}_{5}$.

Regarding the alumina saturation index, $\mathrm{ISA}=\mathrm{Al}_{2}^{2} \mathrm{O}_{3}$ I $\mathrm{CaO}+\mathrm{Na}_{2} \mathrm{O}+\mathrm{K}_{2} \mathrm{O}$ molar or $\mathrm{A} / \mathrm{CNK}$ vs. $\mathrm{A} / \mathrm{NK}$ or alumina index according Maniar and Piccoli (1989 - Figure 17), the rocks analyzed show predominant feature peraluminous. 
Figure 15

Classification of granites of the study area, according to the diagram of Debon and Lefort (1983) for plutonic rocks, leading to main fields: to (tonalite), gd (granodiorite), ad (adamelito), gr (granite), dq (quartz diorite), mzdq (quartz monzodiorite), mzq (quartz monzonite), sq (quartz syenite).

Figure 16

Graphical $\mathrm{MgO} \times \mathrm{TiO}_{2}$ for the granitic

Bois River Suite, where the samples show a tendency for a positive correlation between these major elements.
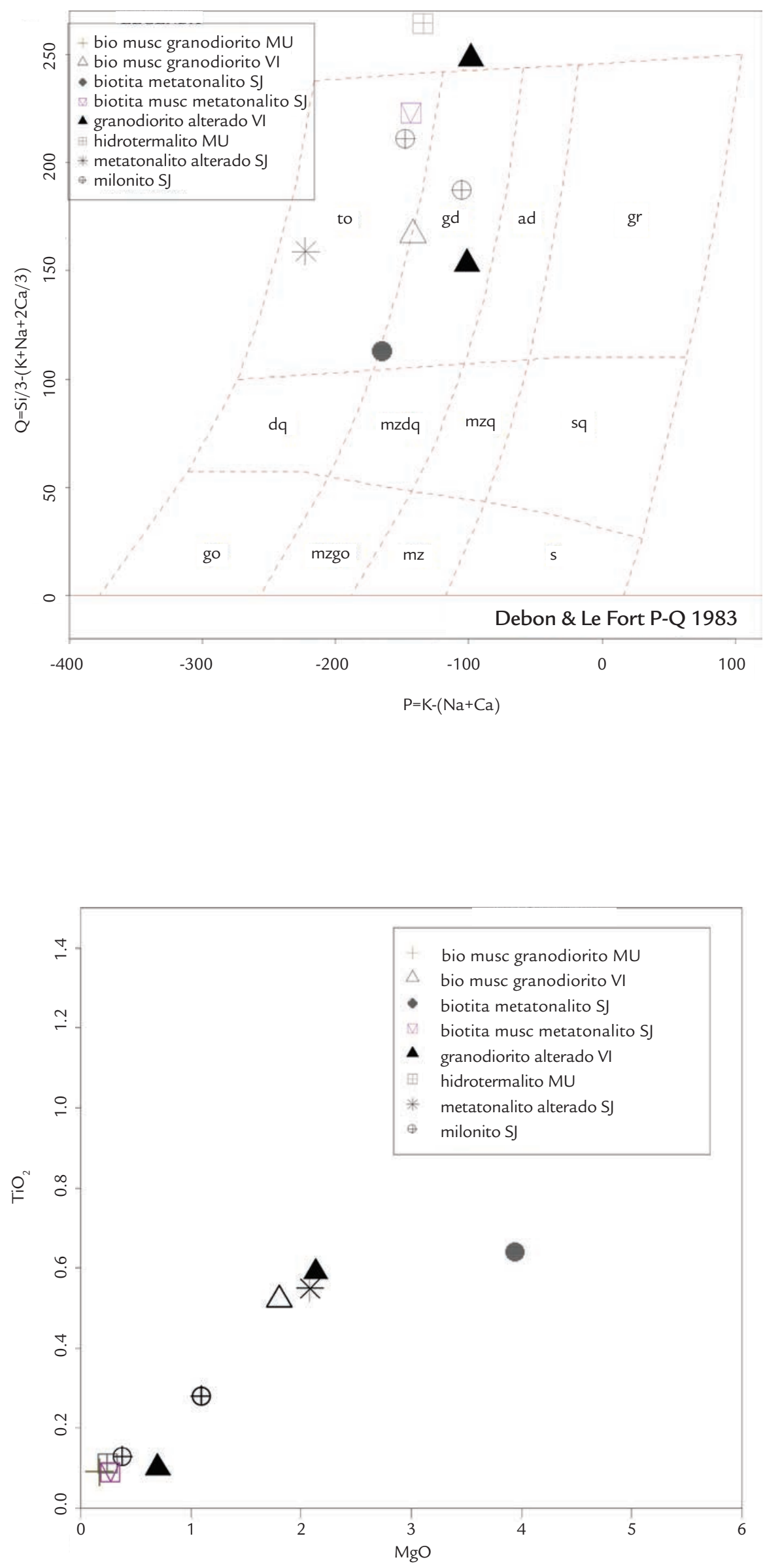


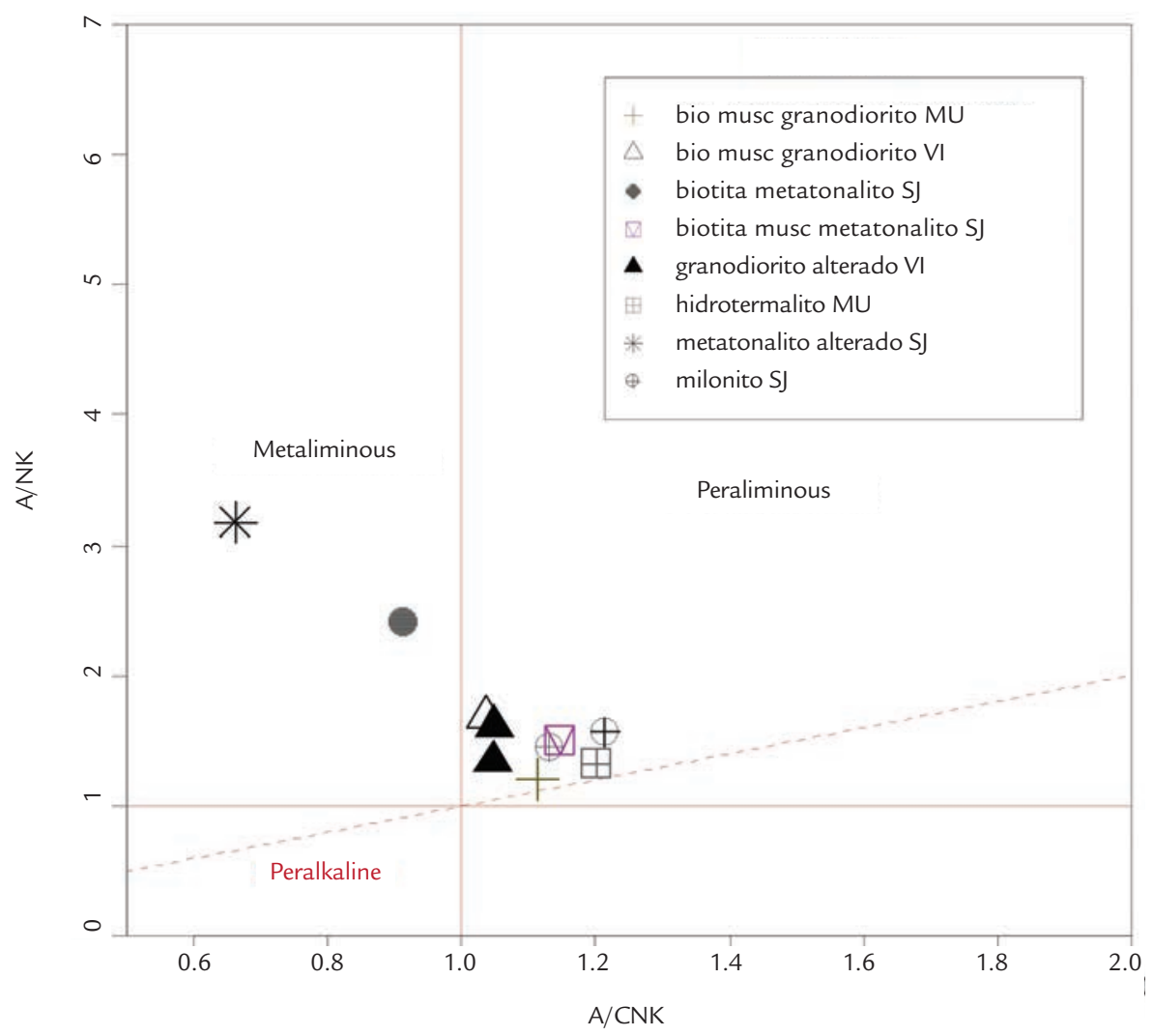

Figure 17

Diagram aluminous, alumina index of granites of Bois River, according to Maniar and Piccoli (1989).
Only in samples Gb and Gc of tonalite SJ, the composition is metaluminous. The difference with this character geochemical metaluminous in SJ types, since their biotite compositions are indicating peraluminous, should chemical changes and rebalancing suffered by biotite, reflecting metasomatic-hydrothermal process in the rock, with enrichment of alumina during this process.

Papers in granites of Australia developed by Blevin and Chappell (1995) relate ISA values $<1.1$ to I-type granites and
ISA $>1.1$ to S-type granite. The tonalitic rocks $\mathrm{Gb}$ and $\mathrm{Gc}$ of the SJ tonalite show ISA values $<1$, while the other rocks values are equal or close to 1.1. In terms of minor elements, granitic rocks have content $\mathrm{BaO}$ between 100 and 670 ppm with great variation to the terms more acidic. The content of yttrium ranges of 10 to $100 \mathrm{ppm}$, and the highest levels found in granodiorite intensely hydrothermalized type VI and MU. Zirconium ranges from 80 to 350 ppm with higher values associated with granodiorite VI and MU.

\subsection{Tectonic setting}

Aiming to investigate the genesis of the granitic Rio dos Bois Suite and the environment of formation of these granitic rocks, drew up discriminant diagrams of lithogeochemistry. In the multicationic graphical R1- R2, Bachelor Bowden (1985) the granodiorite VI samples show characteristics of peraluminous magmatism system syn-collisional to post-collisional, and SJ tonalite with geochemical signature of post-collisional granites (Figure 18). This interpretation agrees with the analysis using the graphics Pearce et al. (1984), where they present post to syn-collisional characteristics.

Applying content $(\mathrm{Nb} / \mathrm{Zr})^{\mathrm{N}}$ vs. Zr normalized to primitive mantle of Sun and McDonough (1989) and according with Thiéblemont and Tégyey (1994), (Figure 19), the Rio dos Bois Suite, falls largely in the field of calc-alkaline magmatism to crustal contamination (field B) or A2/colisional granitoid type with crustal sources, whose ratio $\mathrm{Y} / \mathrm{Nb}$ is above 1.2. Granitic type $\mathrm{A} 1$ ratio $\mathrm{Y} / \mathrm{Nb}$ is less than 1.2 and is characterized by continental intraplate environment or Rift (field C). Within a system of convergent plate margin, this granitogenese corresponds to the later phases of the Arc collisional system. Thus, some samples plots in field on the edge of the calc-alkaline magmatism derived from subduction zone, considering that they evolved from the continental margin Arc of the primitive type of Paleoproterozoic age.

In Figure 20 the best preserved specimens are in the field of syn-collisional to post-collisional granitic, where it is emphasized that types of samples over hydrothermalized are in the field intraplate granites due to $\mathrm{Y}$ enrichement in during the hydrothermal process. 
Figure 18

Geotectonic Diagram R1 x R2 by Batchelor \& Bowden (1985) for the granitoids of Bois River Suite.
Figure 19

Classification geotectonic of granitoides of Bois River Suite, using the contents of $(\mathrm{Nb} / \mathrm{Zr})^{\mathrm{n}} v s$. Zr (Thiéblemont and Tégyey 1994), normalized to primitive mantle of Sun and McDonough (1989); legend as before.
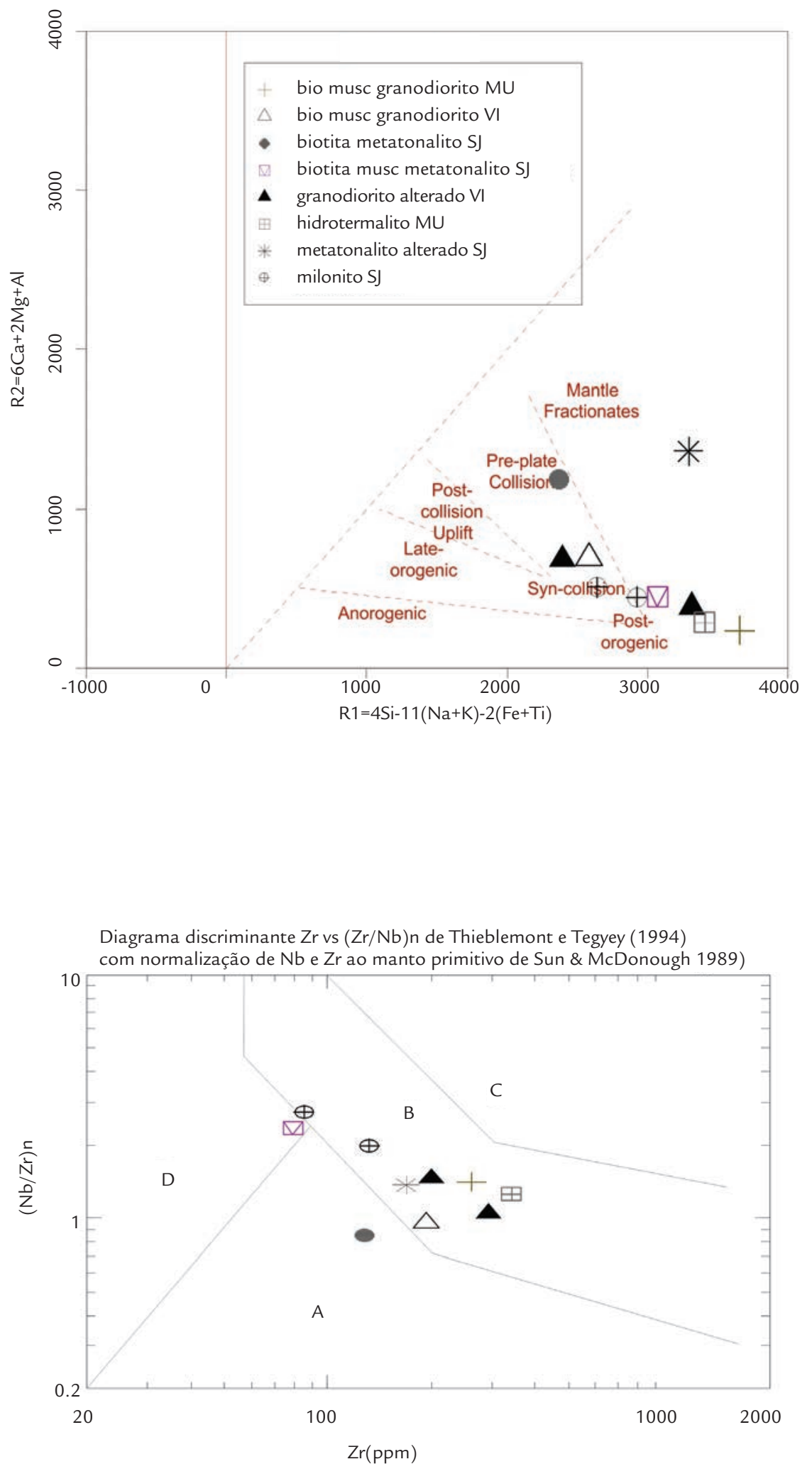

A - campo do magmatismo cálcio-alcalino manto-derivado em zona de subucção

B - campo do magmatismo cálcio-alcalino com contaminação crustal/rochas alcalinas e granitos tipo A2/colisional

C - campo do magmatismo das rochas alcalinas e transicionais intraplaca/granitos tipo A1

D - campo do magmatismo hiperaluminoso/colisão continente-continente 


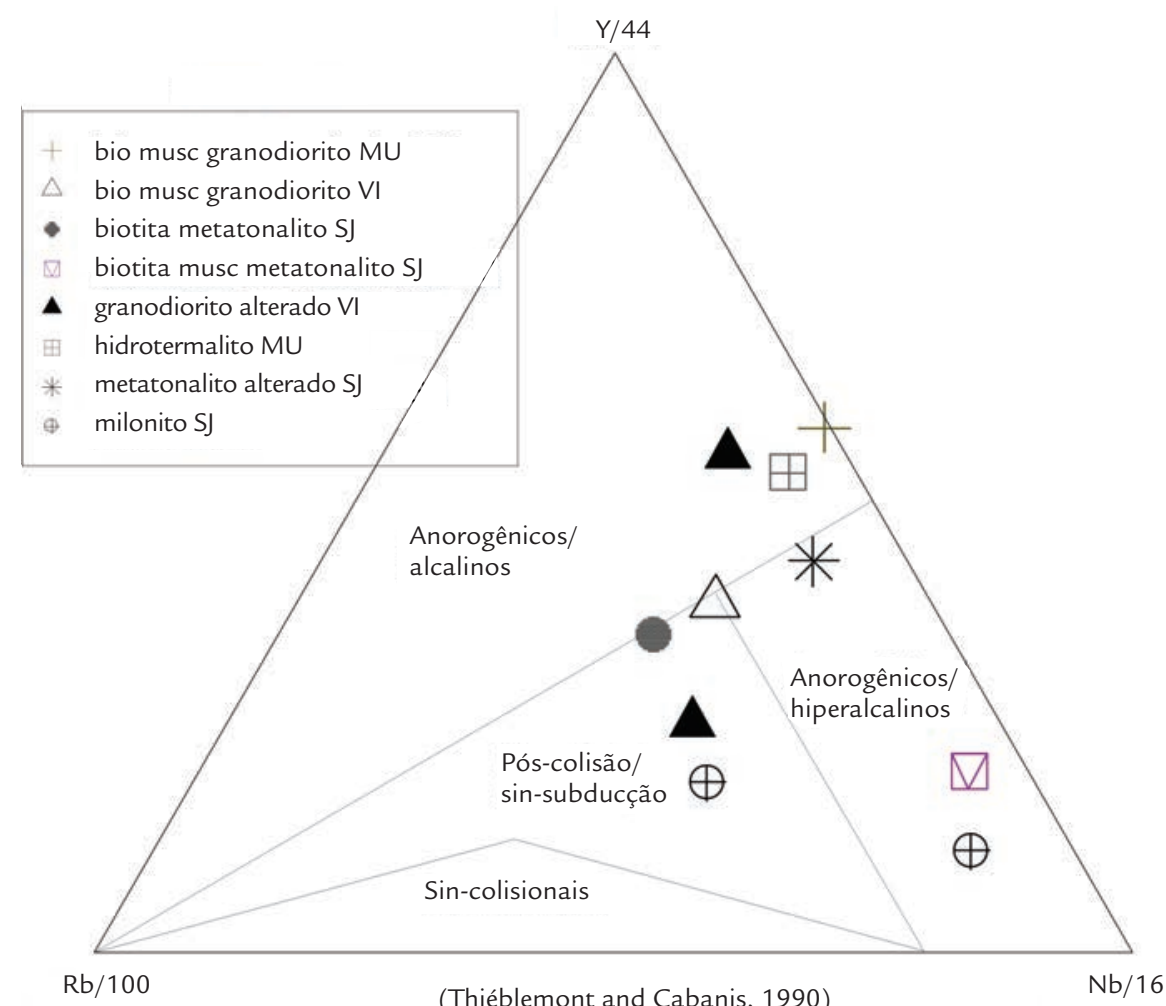

Figure 20

Graphical ternary by Thiéblemont and Cabanis (1990) for the granitoides of Bois River Suite.

\subsection{Trace and rare earth elements geochemistry}

The total content of rare earth elements (REE) in these granites range from moderate in granodiorite VI (105-206 ppm) and granodiorite MU $(69-330 \mathrm{ppm})$ and low in the tonalitic metatonalites SJ (69-124 ppm). The REE patterns of Bois River granite (Figures $21 \mathrm{~A}, \mathrm{~B}, \mathrm{C}$ ) show light rare earth ratios for heavy light rare earth element (LREE)/heavy rare earth element (HREE) values through the ratio $\mathrm{La} / \mathrm{Lu}$. In granodiorite VI (Figure 21B), values are presented from 8 to 10,6 showing small fractionation, and the sample VIA has negative Eu anomally, as observed qualitatively.

The granodiorite MU (Figure 21C) has values from 1.8 to 5.6 featuring small fractionation between light and heavy, while the sample 109 shows larger to moderate fractionation. In tonalite SJ REE values show up moderate to weak fractionation, ranging from 41 to 257 , with positive Europeum $(\mathrm{Eu})$ anomalies due to analytical problems.
In the most altered granitic rocks it can be observed lower fractionation between LREE and HREE, probably indicating that the process of hydrothermal alteration decreased the relative concentrations of REEs due to the homogenization that occurred between the elements.

In multilementar diagrams samples were from a plotted area of Bois River which are characterized generally by negative anomalies of $\mathrm{Nb}, \mathrm{K}, \mathrm{P}$ and $\mathrm{Ti}$, observing a slight to moderate standard large-ion litophile (LIL) fractionation relative to $\mathrm{Y}$ and REE. $\mathrm{Rb}$ concentrations are low in these rocks tending to decrease in more hydrothermalized granites. Despite the few analyzes, these geochemical patterns monitored to large-ion litophile elements (LILE) and high field strength elements (HFSE) and negative anomalies incompatible elements are similar to those observed in granitogenese collisional magmatic arcs and confirming the similarity with calc-alkaline and peraluminous granites. 

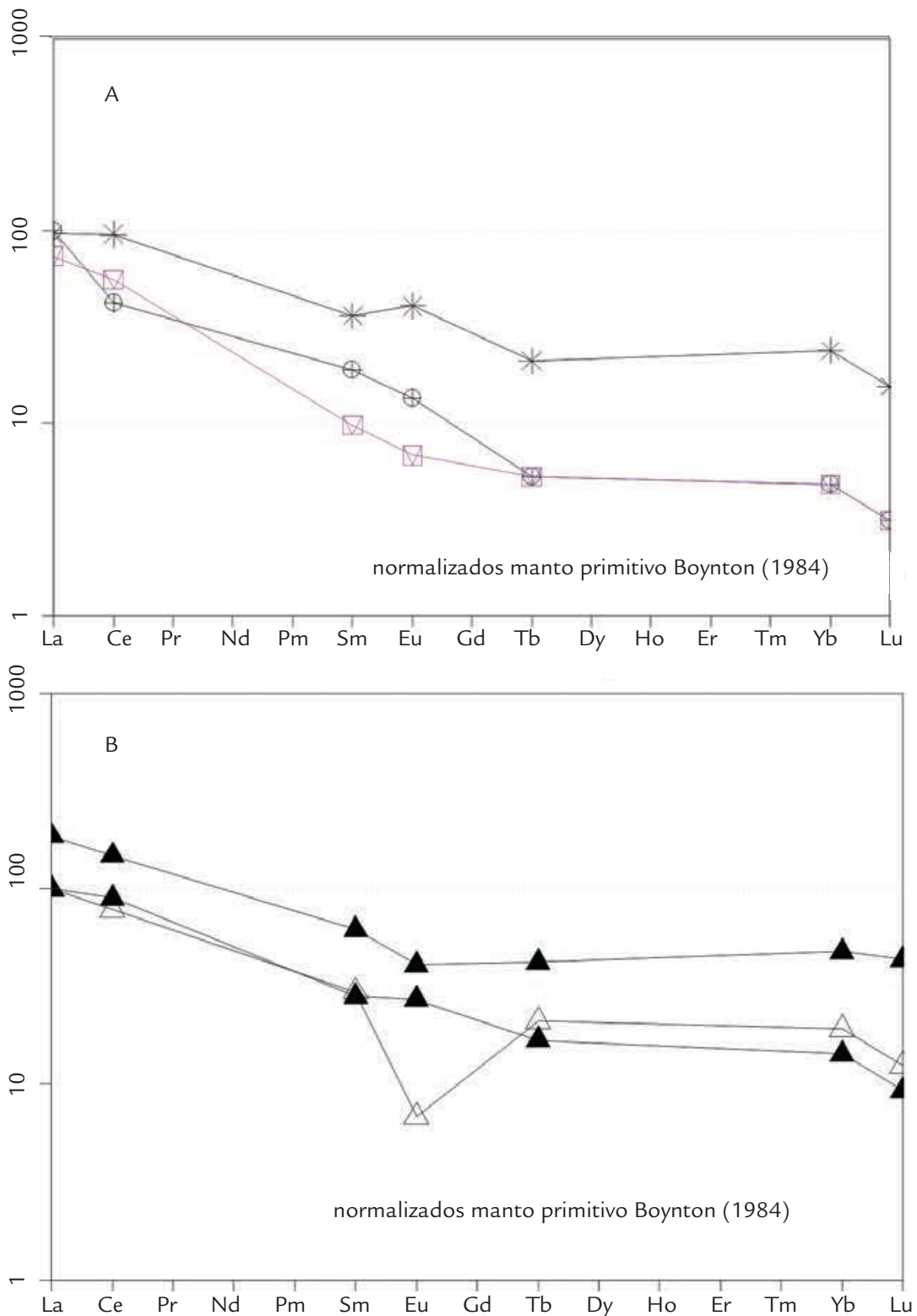

Figure 21

Distribution of rare earth elements to the granitic Bois River Suite; (A) tonalite SJ, (B) granodiorite VI and (C) granodiorite MU.

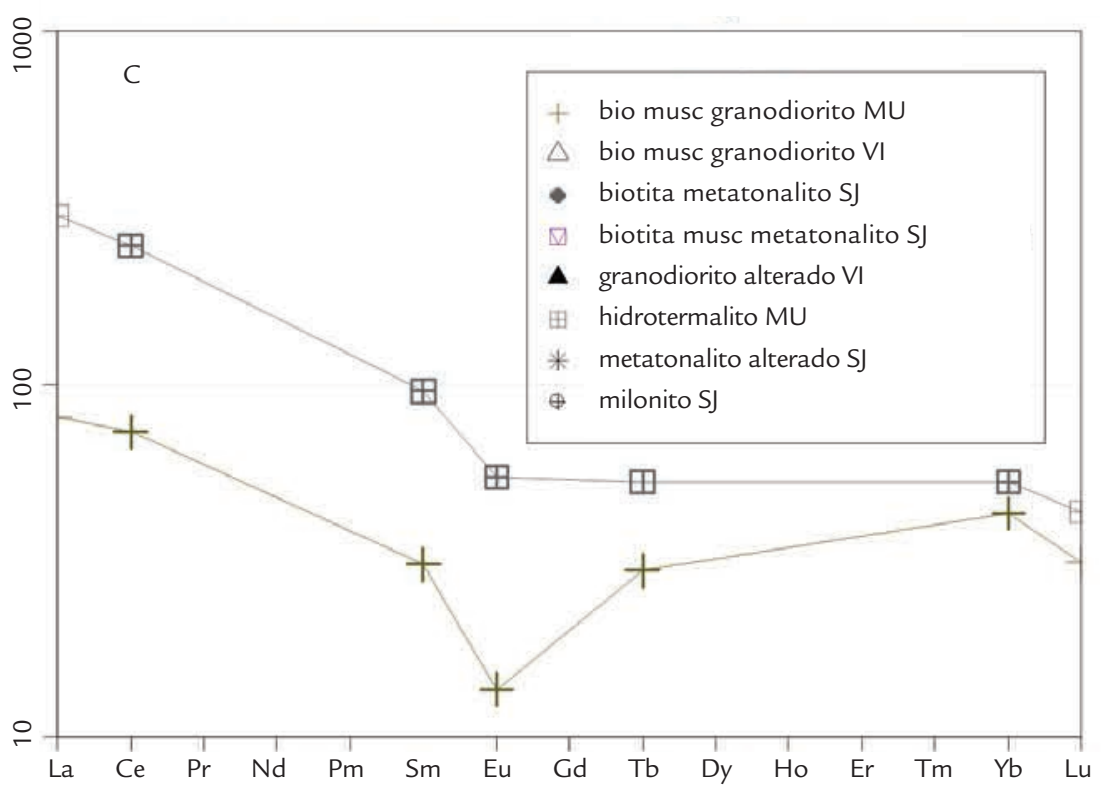




\section{CONCLUSIONS}

In the area Bois River were characterized granitic bodies, mainly granodiorite VI, MU and tonalite SJ; intrusions are small- to medium-sized, well-deformed and intrusive in sequence Campinorte, and occur as NNE-trending elongate plutons showing varied degrees of deformation. The main granite bodies are represented by Mundinho and Viúva intrusions, which host gold deposits related to Au Porphiry in paleoproterozoic transcorrent shear zone.

The classification of these rocks indicates granodioritic to tonalitic composition. The Bois River Suite exhibit characteristics of magmatism, predominantly peraluminous, that are in the field syn-collisional to post-collisional granitic. The samples of more hydrothermalized type are located in the field of granite intraplaque due to enriched in $\mathrm{Y}, \mathrm{Yb}$ and $\mathrm{Ta}$. The $\mathrm{MgO} /$ $\mathrm{TiO}_{2}$ ratios in granites are similar, despite the hydrothermal alteration developed, i.e., these elements have not been significantly modified from the magmatic concentrations. The rocks analyzed show an evolution from the less evolved granites to terms with little $\mathrm{MgO}$ and $\mathrm{TiO}_{2}$ in chemical composition.
Studies of mineral chemistry in biotite and muscovite showed that these minerals have significant compositional variations, i.e., rebalancing physic-chemical related to hydrothermal processes that have acted on the granitic rocks. Three types of biotite designated type I, II, III has been characterized, related to different phases of development of these granites: biotite I, primary, is richer in variety $\mathrm{TiO}_{2}$, biotite type II is primary biotite rebalanced, and type III (magnesian), secondary impoverished in $\mathrm{TiO}_{2}$.

In the ternary diagram $\mathrm{MgO} \times \mathrm{Al}_{2} \mathrm{O}_{3} \times \mathrm{FeO}^{2}$ the biotite of this Suite focuses both on the field of calc-alkaline series, type $\mathrm{C}$ (biotite granodiorite $\mathrm{MU}$ ), as the peraluminous series in tonalite SJ. The white micas analyzed are located near the pole muscovite fhengite, and may qualify them as phengite, both the primary and the secondary. It has been possible to characterize three types of white mica, muscovite I, II and III. The muscovite I is primary magmatic muscovite and II, III type are secondary and intermediate a more aluminous and characterized by lower values of $\mathrm{TiO}_{2}$.

\section{ACKNOWLEDGMENTS}

Special thanks to professor PhD. Nilson Francisquini Botelho for guiding this research work in 2002, the University of Brasilia for the use of laboratories during the Masters and Coordenação de Aperfeiçoamento de Pessoal de Nível Superior (CAPES) for the support of this research.

\section{REFERENCES}

Abdallah S. 2001. Estudo das mineralizações auríferas hospedadas nos granitos Rio dos Bois, Mara Rosa (GO). Dissertação de mestrado, Instituto de Geociências, Universidade de Brasilia, 159 p.

Abdallah S., Botelho N. F. 2002. As mineralizações de ouro hospedados nos granitos da cabeceira do Rio dos Bois, Mara Rosa (GO). In: SBG, XLI Cong. Bras. de Geologia, Abstracts, p. 207.

Abdallah S. 2011. Interpretação litogeoquímica das rochas graníticas da folha Arraias. In: SBG, XIII Congresso Brasileiro de Geoquímica, III Simpósio Geoquímica dos países do Mercosul, anais CD, p.848-851.

Abdel-Rahman A.M. 1994. Nature of biotites from alkaline, calc-alkaline and peraluminous magmas, Journal Petrology, 35:525-541.

Arantes D., Buck P.S., Osborne G.A., Porto C.G. 1991. A Sequência vulcano-sedimentar de Mara Rosa e as mineralizações auríferas associadas. In: SBG, Núcleo Centro-Oeste, Boletim informativo, p. 27-40.

Blevin P. L., Chappell B.W. 1995. Chemistry, origin and evolution of mineralized granites in the Lachlan Fold Belt, Austrália: The metallogeny of I and S-type granites, Economic Geology, 90:1604-1619.

Batchelor R.A., Bowden P. 1985. Petrogenetic interpretation of granitoid series using multicationic parameter, Chemical Geology, 48:43-55.

Danni J.C.M., Ribeiro C.C. 1978. Caracterização estratigráfica da Sequência vulcano-sedimentar de Pilar de Goiás e Guarinos, Goiás. In: SBG, II Congresso Brasileiro de Geologia, Atas, p. 582-596. 
Debon F., LeFort P. 1988. A cationic classification of common plutonic rocks and their magmatic associations: principles, method, applications, Bulletin of Mineral, 111:493-510.

Deer W.A., Howie R.A., Zussman J. 1992. An introduction to the rock-forming minerals. 2. ed. Longman Scientific \& Technical, Hong Kong, 696 p.

Fuck R.A. 1994. A Faixa Brasília e a compartimentacão tectônica na Província Tocantins. In: SBG, Núcleos de Brasília e Centro-Oeste, IV Simpósio de Geologia do Centro-oeste, p. 184-187.

Giustina, M.E. 2007. Geologia e Geocronologia da Sequência Vulcanosedimentar Campinorte e do Complexo Uruaçu, porção central do Maciço de Goiás. Dissertação de Mestrado, Instituto de Geociências, Universidade de Brasília, 83 p.

Kretz R. 1983. Symbols for rock-forming minerals, American Mineralogy, 68:277-279.

Kuyumjian R.M. 1994. A sequência Mara Rosa na região da Chapada, Goiás. In: SBG, Núcleo Brasília, Boletim Informativo, 17:34-38.

Kuyumjian R.M., Oliveira C.G., Campos J.E.G., Queiroz C.L. 2004. Geologia do limite entre os terrenos arqueanos e o arco magmático de Goiás na região de Chapada-Campinorte, Goiás, Revista Brasileira de Geociências, 34: 329-334.

Lacerda H. 1986. As mineralizações auríferas da região de Mara Rosa (GO), Revista Brasileira de Geociências, 16:274-284.

Maniar P.D., Piccoli P.M. 1989. Tectonic discrimination of granitoids, Bulletin of the Geological Society of America, 101:635-643.

Marini O.J., Fuck R.A., Dardenne M.A., Danni J.C.M. 1984. Província Tocantins, setores central e sudeste. In: Almeida F.F.M. \& Hasui Y. (eds.) O PréCambriano do Brasil. São Paulo, Edgard Blucher, p. 87-264.

Marini O.J., Fuck R,A., Dardenne M.A., Faria A. 1977. Contribuição à geologia do pré-cambriano da porção central de Goiás, Revista Brasileira de Geociências, 7:304-324.

Monier G., Robert J.L. 1986. Titanium in muscovite from two mica granites: substitutional mechanism and partition with coexisting biotites. Neues Jahrbuch Mineral Abh., 153:147-161.

Nachit H. 1986. Contribution à l'étude analytique et expérimentale des biotites des granitoïdes. Applications typologiques, Tese de doutoramento, Université de Bretagne Occidentale, $181 \mathrm{p}$.

Pearce J.A., Harris N.B.W., Tindle A.G. 1984. Trace element discrimination diagrams for the tectonic interpretation of granitic rocks, Journal Petrology, 25:956-983.

Pimentel M.M., Fuck R.A. 1992. Neoproterozoic crustal accretion in central Brasil. Geology, 20:375-379.

Pimentel M.M., Whitehouse M.J., Viana M.G., Fuck R.A., Machado N. 1997. The Mara Rosa Arc in the Tocantins Province: further evidence for Neoproterozoic crustal accretion in Central Brazil, Precambrian Research, 81:299-310.

Ribeiro Filho W. 1981. Reavaliação da geologia de Pilar-Mara Rosa. In: SBG, Núcleo Centro-Oeste, I Simpósio de Geologia do Centro-Oeste, Atas, p. 281-296.

Rieder M., Cavazzini G., D’Yakonov Y. S., Frank-Kamenetskii V. A., Gottardi G., Guggenheim S., Koval P. V., Muller G., Neiva A.M.R., Radoslovich E. W., Robert J-L, Sassi F. P., Takeda H., Weiss Z., Wones D. R. 1998. Nomenclature of the Micas, Canadian Mineral, 36:905-912.

Silva J.A., Sá J.A.G. 1988. Jazida de cobre de Chapada, Mara Rosa, Goiás. In: C. Schobbenhaus (ed.) Principais depósitos minerais do Brasil, DNPM/CVRD, 3, p. 55-60.

Sun S.S., McDonough W,F. 1989. Chemical and isotopic systematics of oceanic basalts: implications for mantle compostion and processes. In: Saunders A.D. \& Norry M.J. (eds.) Magmatism in the Ocean Basins. Geological Society Special Publication, 42, p. 313-345. 
Thiéblemont D., Cabanis B. 1990. Utilisation d'un diagramme (Rb/100)-Tb-Ta pour la discrimination géochimique et l'étude pétrogénétique des roches magmatiques acides, Bulletin de la Societé Geólogique de France, 8:23-35.

Thieblemont D., Tégyey M. 1994. Geochemical discrimination of differentiated magmatic rocks attesting for the variable origin and tectonic setting of Calc-alkaline magmas, Comptes rendus de l'Academie des sciences, Serie 2, Mecanique, physique, chimie, sciences de l'univers, sciences de la terre, 319:87-94.

Viana M.G. 1995. Geocronologia e geoquímica das rochas ortognáissicas e metavulcânicas da região de Mara Rosa, norte de Goiás, Dissertação de Mestrado, Instituto de Geociências, Universidade de Brasília, 110 p. 